
Cochlea-Implantat-Chirurgie: Eine prospektive Studie zur

Evaluation eines dreidimensionalen, präoperativen

Bildverarbeitungsprogrammes („CI-Wizard“)

\section{DISSERTATION}

zur Erlangung des akademischen Grades

Dr. med.

an der Medizinischen Fakultät

der Universität Leipzig

eingereicht von:

Frau Mary Tittmann

Geburtsdatum / Geburtsort:

25.02.1988 / Karl-Marx-Stadt, j. Chemnitz

angefertigt am:

Universitätsklinikum Leipzig AöR, Klinik und Poliklinik für Hals,- Nasen,- Ohrenheilkunde

Direktor: Prof. Dr. med. Andreas Dietz

\section{Betreuer:}

Prof Dr. med. Andreas Dietz

Dr. med. Mathias Hofer

Dr. med. Markus Pirlich

Beschluss über die Verleihung des Doktorgrades vom 21/08/2018 
1 Einführung 1

1.1 Cochlea Implantate (CI) 1

1.2 Bildverarbeitungsprogamme zur präoperativen Planung eines Cochlea Implantates $\quad 2$

1.2.1 Segmentierung in der Medizin $\quad 2$

1.2.2 CI-Wizard 4

1.3 Fragebogen 6

$\begin{array}{lll}1.4 & \text { Zielsetzung } & 6\end{array}$

$\begin{array}{lll}1.5 & \text { Zusammenfassung der Ergebnisse } & 7\end{array}$

2 Publikation $\quad 8$

3 Zusammenfassung 19

4 Literaturverzeichnis 23

$\begin{array}{ll}\text { Anlagen } & 26\end{array}$

Beitrag der Promovendin bei geteilter Erstautorenschaft 34

Erklärung über die eigenständige Abfassung der Arbeit 35

Lebenslauf $\quad 36$

$\begin{array}{ll}\text { Danksagung } & 38\end{array}$ 


\section{Einführung}

[...] O, ibr Menschen, die ibr mich für feindseelig, störrisch oder misantropisch haltet oder erkläret, wie unrecht thut ibr mir, ihr wißst nicht die geheime Ursache von dem, was euch so scheinet. . . (dessen Heilung vielleicht Jahre dauren oder gar unmöglich ist) . . . drum verzeibt, wenn ibr mich da zurückweichen seben werdet, wo ich mich gern unter euch mischte, doppelt wehe thut mir mein Unglück, indem ich dabei verkannt werde, ... wie ein Verbannter muß ich leben, ... welche Demüthigung wenn jemand neben mir stund und von weitem eine Flöte börte und ich nichts börte, oder jemand den Hirten Singen börte, und ich auch nichts börte, solche Ereignisse brachten mich nahe an die Verzweiflung, es feblte wenig und ich endigte selbst mein Leben - nur sie die Kunst, sie bielt mich zurück, ach es dünkte mir unmöglich, die Welt eher zu verlassen, bis ich das alles hervorgebracht, wozu ich mich aufgelegt füblte [...]

\section{Ludwig van Beethoven, Heiglnstadt [Heiligenstadt] am 6ten October 1802.}

Ein Cochlea Implantat nach dem heutigen Kenntnisstand hätte Ludwig van Beethoven zwar nicht heilen, ihm aber eventuell helfen können (Zenner, 2002). Die Entwicklung des heutigen Cochlea Implantates reicht in der Geschichte bis in die Zeit Beethovens zurück. Pionierarbeit durch die direkte Stimulation des Hörnervs gelang 1957 André Djourno und Charles Eyriès (Mudry \& Mills, 2013). Die erste intracochleäre, einkanalige Elektrode implantierten William House und John Doyle 1961 in Kalifornien (Mudry \& Mills, 2013). Den Grundstein für die heutige Technik, im Sinne eines Zugangs über das runde Fenster in die Cochlea unter Verwendung einer mehrkanaligen Elektrode, legte G. M. Clark im Jahre 1978 (Clark et al., 1978).

\subsection{Cochlea Implantate (CI)}

Cochlea Implantate stellen eine therapeutische Option für Patienten mit angeborenem oder erworbenem Hörverlust durch Beschädigung der Haarzellen bei residual erhaltenem Nervus vestibulocochlearis dar. Die direkte Stimulation des Hörnervs durch intracochleär liegende, mehrkanalige Elektroden, kann nach anschließendem Hörtraining das Hörvermögen und die anschließende Lebensqualität enorm verbessern (Stjernholm, 2003; Bichey et al., 2002).

Funktionsweise: Aktuell verwendete Cochlea Implantat Systeme bestehen aus einem externen, retroaurikulär platziertem Anteil (Mikrofon, Sprachprozessor, Batterie, externe Spule) und einem internen Anteil (interne Spule, Signalprozessor, mehrkanalige Elektroden). Dabei treffen Schallwellen aus der Umgebung auf das Mikrofon, werden dort verstärkt und an den Sprachprozessor weitergeleitet. Dieser wandelt Schallwellen in digital kodierte Informationen um. Über die Spulen nach intern geleitete Signale werden decodiert und in elektrische Signale umgewandelt. Diese werden über die intracochleär verlaufenden Elektroden an den Nervus vestibulocochlearis unter Umgehung des Mittelohres und der Haarzellen im Innenohr geleitet. Im Gehirn werden diese Informationen weiter verarbeitet (Stjernholm C, 2003). 
Operation und Risikostrukturen: Konventionelle CI-Chirurgie verläuft nach einem standardisierten Ablauf. Nach retroauriculärem Zugang, anschließender Mastoidektomie und posteriorer Tympanotomie stellt sich der Nervus facialis als Risikostruktur dar. Besonders der Winkel von Nervus facialis und Chorda tympani ist von Interesse, da er einen kleinen Raum von 2,5-3 mm darstellt (Bielamowicz et al., 1988; Su et al., 1982), durch den die Cochleaelektrode, unter äußerster Schonung der Nerven, hindurch geleitet werden muss. Ferner ist das fenestra cochleae als weitere Risikostruktur zu werten, da die Eröffnung der Rundfenstermembran im Sinne einer Cochleostomie die Voraussetzung zur Einführung einer Cochleaelektrode in die Skala tympani darstellt (Roland et al., 2007). Zur besseren Vorstellung der komplexen Anatomie von Mittel-und Innenohr des Patienten, kann eine dreidimensionale, präoperative Visualisierung des Situs das Risiko von Komplikationen während der Operation vermindern (Todt et al., 2014). Zur präoperativen, dreidimensionalen Visualisierung der lateralen Schädelbasis orientiert sich die vorliegende Arbeit an acht anatomischen Landmarken und Risikostrukturen: (1) Meatus acusticus externus, (2) Ossicula auditus, (3) Cavum tympani, (4) Nervus facialis, (5) Chorda tympani, (6) Fenestra cochleae, (7) Cochlea, (8) Ductus semicirculares.

\subsection{Bildverarbeitungsprogramme zur präoperativen Planung eines Cochlea Implantates}

\subsubsection{Segmentierung in der Medizin}

Segmentierung bezeichnet in der Medizin einen digitalen Bildverarbeitungsprozess, um inhaltlich zusammenhängende Pixel (2D) oder Voxel (3D) zuzuordnen (Suetens et al., 1993; Anderson \& Barrett, 2007). Auf Basis einer zweidimensionalen Bildgebung (Computertomographie oder Magnetresonanztomographie) verwenden Bildverarbeitungsprogramme verschiedene Segmentierungsalgorithmen, um eine dreidimensionale Ansicht einer medizinisch relevanten Region zu erreichen (Suetens et al., 1993; Ferreira et al., 2014). Aufgrund der komplexen anatomischen Verhältnisse der lateralen Schädelbasis, erleichtern dreidimensionale Bilder die Vorstellung der individuellen Anatomie des Patienten präoperativ (Rodt et al., 2002). In den letzten Jahrzehnten wurden die Bildverarbeitungsprogramme stets weiterentwickelt (Zhen et al., 2010). Inzwischen existieren verschiedene Algorithmen. Bei der manuellen Segmentierung werden beispielsweise die Konturen vom Benutzer Schicht für Schicht segmentiert (Sim \& Puria, 2008). Dieser Prozess ist meist sehr zeitaufwändig (Noble et al., 2009; Rodt et al., 2002) und für den klinischen Alltag nicht praktikabel. Semiautomatische Algorithmen wirken dem entgegen und 
vereinfachen, beziehungsweise beschleunigen den Segmentierungsprozess (Rodt et al., 2002; Zhen et al., 2010). Anhand ausgewählter Studien vermittelt die Tabelle 1 einen Eindruck über verschiedene Bildverarbeitungsprogramme, denen unterschiedliche Algorithmen zugrunde liegen. Über die verschiedenen Fragestellungen der Studien hinaus bleiben zur Beurteilung der klinischen Praktikabilität stets die zentralen Fragen bestehen, in welcher Zeit und wie akkurat die dreidimensionale Zielansicht mittels dieser Bildverarbeitungsprogramme erreicht werden kann. Wenige Studien beachten beide Kernfragen. Primäres Ziel dieser Studie ist ein neues Bildverarbeitungsprogramm in Zusammenschau beider Kriterien $\mathrm{zu}$ evaluieren und eine Umsetzbarkeit im klinischen Alltag zu diskutieren. 
Tabelle I: Charakteristiken und Ergebnisse ausgewählter Studien zu verschiedenen Bildverarbeitungsprogrammen im Rahmen der CI-Chirurgie

\begin{tabular}{|c|c|c|c|c|c|}
\hline Studie & lverarbeitungsprogramm & Algorithmus & $\mathrm{n}^{\mathrm{a}}$ & $\begin{array}{l}\text { Ziel der } \\
\text { Studie }\end{array}$ & Ergebnisse \\
\hline $\begin{array}{l}\text { Kisser et al. } \\
\text { (2014) }\end{array}$ & - OsiriX softwareb & $\begin{array}{l}\text { 3D-curved } \\
\text { multiplanar } \\
\text { reconstruction } \\
(\mathrm{MPR}) \text { analysis }\end{array}$ & 9 & $\begin{array}{l}\text { Vorhersage der } \\
\text { Länge des zu } \\
\text { verwendeten } \\
\text { Cochlea } \\
\text { Implantates }\end{array}$ & $\begin{array}{l}\text { Zeitaufwand: } \\
\mathrm{t}=6.1 \text { ( } \pm 3.4) \\
\min \\
\text { Genauigkeit: } \\
0.8( \pm 0.7) \\
\mathrm{mm}\end{array}$ \\
\hline $\begin{array}{l}\text { Gerber et al. } \\
\text { (2013) }\end{array}$ & $\begin{array}{l}\text { - QTc } \\
\text { - Open Inventor }{ }^{\mathrm{d}} \\
\text { - DICOM Toolkit } \\
\text { - Visualization } \\
\text { Toolkit }^{\mathrm{f}} \\
\text { - Insight } \\
\text { Segmentation and } \\
\text { Registration Toolkitg }\end{array}$ & $\begin{array}{l}\text { Marching cube } \\
\text { algorithm, } \\
\text { Curved planar } \\
\text { reconstruction } \\
\text { (CPR) }\end{array}$ & 10 & $\begin{array}{l}\text { Vorstellung } \\
\text { eines } \\
\text { chirurgischen } \\
\text { Planungswerk- } \\
\text { zeugs zur } \\
\text { roboter- } \\
\text { assistierten } \\
\text { Cochlea } \\
\text { Implantation }\end{array}$ & $\begin{array}{l}\text { Zeitaufwand: } \\
\mathrm{t}=15.95 \mathrm{~min} \\
\text { Genanigkeit: } \\
0.15 \pm 0.08 \\
\mathrm{~mm}\end{array}$ \\
\hline $\begin{array}{l}\text { Majdani et al. } \\
(2009)\end{array}$ & - iPlan 2.6 & $\begin{array}{l}\text { Semiautomatic } \\
\text { segmentation } \\
\text { with threshold } \\
\text { algorithms and } \\
\text { manual } \\
\text { corrections }\end{array}$ & 10 & $\begin{array}{l}\text { Planung eines } \\
\text { roboter- } \\
\text { gesteuerten } \\
\text { Zugangs für } \\
\text { CI-Chirurgie }\end{array}$ & $\begin{array}{l}\text { Zeitaufwand: } \\
\text { nicht } \\
\text { bekannt } \\
\text { Genanigkeit: } \\
0.78 \text { ( } \pm 0.29) \\
\mathrm{mm}\end{array}$ \\
\hline $\begin{array}{l}\text { Todt et al. } \\
\text { (2014) }\end{array}$ & - ZIBAmira & Nicht bekannt & 30 & $\begin{array}{l}\text { Preoperative } \\
\text { Bestimmung } \\
\text { der B-FMT } \\
\text { Position } \\
\text { (Vibrant } \\
\text { Bonebridge) }\end{array}$ & $\begin{array}{l}\text { Zeitaufwand: } \\
\mathrm{t}=1.5 \text { min } \\
\text { Genauigkeit: } \\
\text { nicht } \\
\text { bekannt }\end{array}$ \\
\hline $\begin{array}{l}\text { Rodt et al. } \\
(2002)\end{array}$ & $\begin{array}{l}\text { - 3D-Slicer }{ }^{\mathrm{i}} \\
\text { - Mrxi } \\
\text { - VTKk }\end{array}$ & $\begin{array}{l}\text { Threshold } \\
\text { algorithms } \\
\text { combined with } \\
\text { manual } \\
\text { segmentation, } \\
\text { Marching cube } \\
\text { algorithm }\end{array}$ & 17 & $\begin{array}{l}\text { 3D } \\
\text { Visualisierung } \\
\text { des Mittelohres } \\
\text { und seiner } \\
\text { angrenzenden } \\
\text { Strukturen }\end{array}$ & $\begin{array}{l}\text { Zeitanfwand: } \\
6 \text { Stunden } \\
\text { Genanigkeit: } \\
\text { nicht } \\
\text { bekannt }\end{array}$ \\
\hline
\end{tabular}

${ }^{\mathrm{a}} \mathrm{n}=$ Anzahl der dreidimensional dargestellten anatomischen Zielstrukturen; ${ }^{\mathrm{b}}$ version 4.1, 64bit; ' $\mathrm{Digia}$, Helsinki, Finland, ${ }^{\mathrm{d} C o i n}$ 3D, Kongsberg, Norway; ${ }^{\mathrm{D} D C M T K}$, OFFIS computer science institute, Germany; ${ }^{\mathrm{f} V T K}$, Kitware Inc., USA; ${ }^{\mathrm{g} I T K}$,

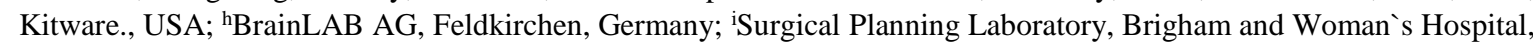

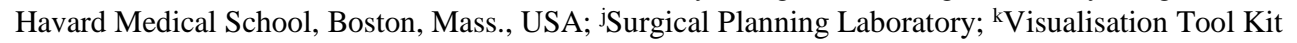




\subsubsection{CI-Wizard}

CI-Wizard bezeichnet ein neu entwickeltes Bildverarbeitungsprogramm zur dreidimensionalen Visualisierung der anatomischen Risikostrukturen im Rahmen der präoperativen Planung eines Cochlea Implantates (Franz, 2016). Der CI-Wizard wurde mit dem Ziel entwickelt, die semantische Lücke zwischen informatischen Bildverarbeitungsprozessen und der klinischen Anwendung dieser Planungswerkzeuge durch den medizinischen Experten zu schließen. Grundlage zur Übersetzung komplexer Bildverarbeitungsprozesse in eine problemorientierte medizinische Terminologie bildet der „wizard interaction pattern“ (Tidwell, 2005). Diese Wizard (engl. „Zauberer") basierte Segmentierung ermöglicht dem Operateur, sich präoperativ auf die Bilddaten zu konzentrieren ohne sich den Details der Bildverarbeitung widmen zu müssen. Der CI-Wizard basiert auf computertomographischen Bildern der Auflösung von $0,24 \mathrm{~mm}^{2}(\sigma=0.07)$ pixel und einem Schichtabstand von $0,4 \mathrm{~mm}(\sigma=0.29)$ und stützt sich auf das Wissen, das die meisten anatomischen Strukturen des Mittel- und Innenohres eingebettet von knöchernen Strukturen liegen. Mit der zusätzlichen Einbeziehung anatomischer Durchschnittswerte (Länge, Volumen, etc.) werden Schwellenwerte berechnet. Zudem wurde ein Algorithmus definiert, der zusammenhängende Regionen in axialer Richtung Schicht um Schicht detektiert. Die Vereinigung dieser Kriterien generiert dem Benutzer eine dreidimensionale Ansicht der Zielstruktur. Nach jedem Schritt erhält der Benutzer ein visuelles Feedback. Mittels manueller Segmentierung ist es medizinischen Experten möglich, die anatomischen Strukturen zu verändern und anzupassen. Abbildung I stellt eine vereinfachte schematische Segmentierungspipeline aller zu segmentierenden anatomischen Risikostrukturen von lateral nach medial dar.

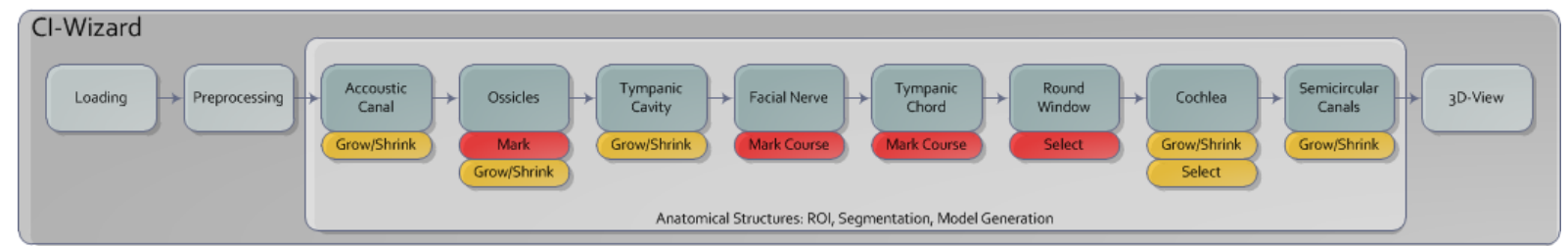

Abbildung I: Schematische Darstellung der Segmentierung anatomischer Risikostrukturen von lateral nach medial gelb-Modifizierungsmöglichkeiten der Zielansicbt durch den Benutzer; rot - notwendige manuelle Segmentierungsscbritte durch den Benutzer 
Abbildung II zeigt beispielhaft die Umsetzung der Segmentierungspipeline und der informatischen Bildverarbeitungsprozesse auf der Höhe der Ossicula auditus. Das Kommunikations- und Arbeitsfenster des Programmes ist in vier Bereiche gegliedert. Bereich a - c zeigt die zweidimensionale CT-Ansicht in axialer (a), sagittaler (b) und coronarer (c) Schnittführung. In diesen Arbeitsfenstern segmentiert der Benutzer die anatomischen Risikostrukturen und erhält sofort ein visuelles dreidimensionales Feedback im Bereich d.

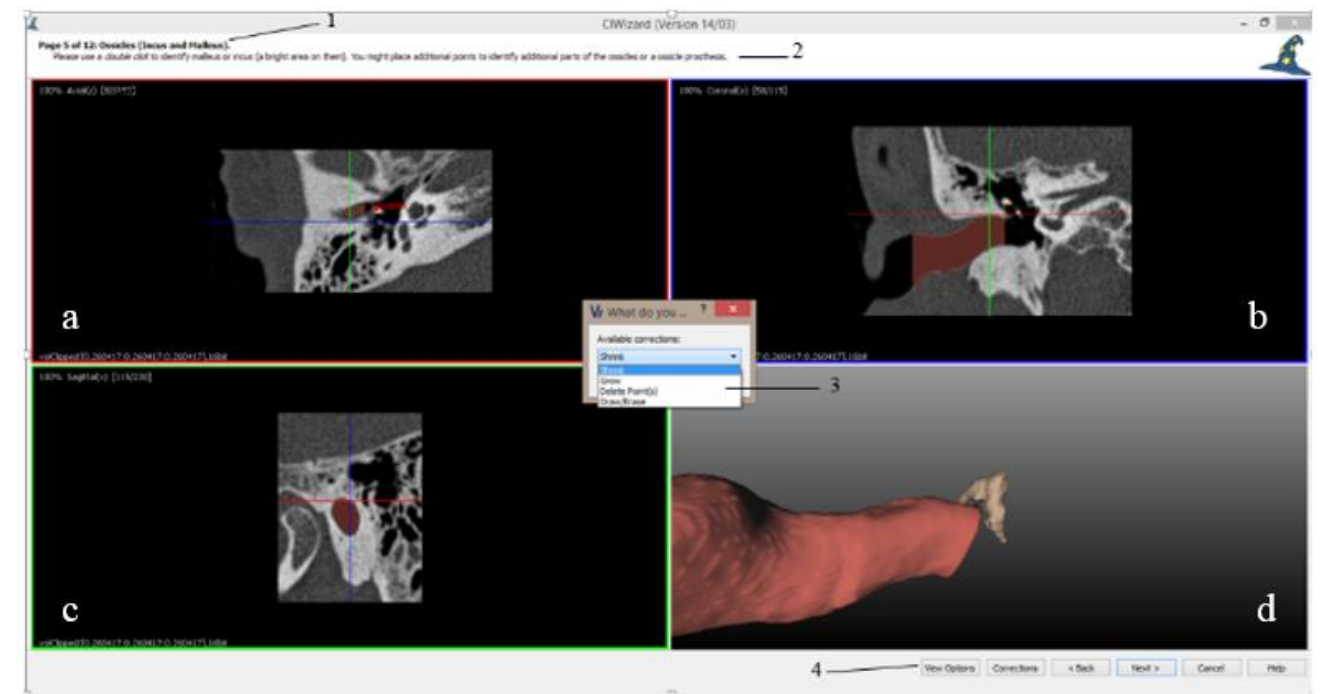

Abbildung II: Arbeitsfenster des CI-Wizard beispielhaft die Segmentierung der Ossicula auditus

$a=C T$ in axialer Schnitffübrung; $b=C T$ in sagitaler Schnitffübrung; $c=C T$ in coronarer Schnittfübrung; $d=$ dreidimensionale Ansicbt der bereits segmentierten anatomischen Strukturen, 1 = Seite der zu segmentierenden anatomischen Struktur; 2 = Anleitung; $3=$ Korrigiermöglichkeiten; $4=$ Navigationsmöglichkeiten

Abbildung III zeigt die finale Ansicht zur präoperativen Planung des Cochlea Implantates und visualisiert die individuellen anatomischen Verhältnisse und Risikostrukturen des Patienten.

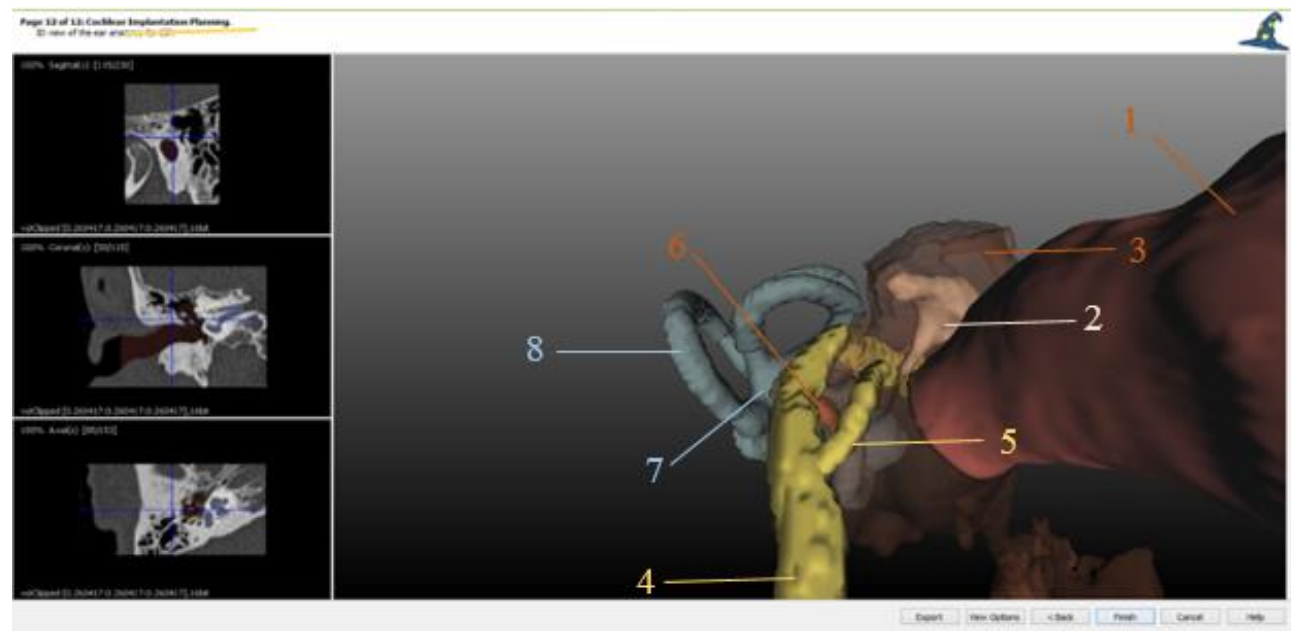

Abbildung III: Zielansicht zur dreidimensionalen Visualisierung der anatomischen Risikostrukturen der lateralen Schädelbasis zur präoperativen CI Planung

$1=$ Meatus acusticus externus; $2=$ Ossicula auditus; $3=$ Cavum tympani; $4=$ Nervus facialis; 5 = Chorda tympani; $6=$ Fenestra cocbleae; $7=$ Cocblea; $8=$ Ductus semicirculares 


\section{$1.3 \quad$ Fragebogen}

Um neben den objektiven Kriterien (Zeitaufwand und Genauigkeit), ein subjektives Maß hinsichtlich der Bedienbarkeit, der Güte der Segmentierung einzelner Strukturen und des empfundenen zeitlichen Aufwandes zu erfassen und quantifizieren zu können, entwickelten wir einen Fragebogen (siehe Anlage B). Dieser wurde von jedem Probanden im Anschluss an die Segmentierungen der Datensätze bearbeitet. Neben der Erhebung soziodemographischer Daten (Alter, Geschlecht, Fachdisziplin) wurden zunächst Items zur Kategorisierung der medizinischen Expertise (Berufserfahrung, Anzahl der jährlich durchgeführten chirurgischen Eingriffe, Anzahl der jährlich durchgeführten Cochlea Implantate, Erfahrungsstand im Umgang mit CT Daten, Ohranatomie, medizinische Computersoftware und Segmentierungsvorerfahrungen) abgefragt. Im Hauptteil des Fragebogens wurde die Qualität der Segmentierbarkeit einzelner anatomischer Strukturen für jeden Datensatz (1-4) erfasst. Dabei wurde jede segmentierte anatomische Struktur anhand einer Rating-Antwortskala von 0 (,gar nicht) bis 5 („,sehr gut“) beurteilt. Zur Einschätzung der Bedienbarkeit des Bildverarbeitungsprogrammes diente die Rating-Skala von 1 (,,sehr gut") bis 4 („,ungenügend“). Eine weitere Ratingskala von 1 (,sehr gering“) bis 4 (,sehr hoch“) ermittelte den subjektiv eingeschätzten Zeitaufwand. Raum für Anmerkungen wurde abschließend in Form eines Freitextes ermöglicht.

\subsection{Zielsetzung}

Primäre Endpunkte der vorliegenden Arbeit sind einerseits die Benutzerfreundlichkeit des Bildverarbeitungsprogrammes CI-Wizard zu evaluieren (1). Andererseits soll die Genauigkeit der individuellen Segmentierungen der Probanden mit einem Goldstandard verglichen werden (2). Darüber hinaus wird der subjektiv empfundene Zeitaufwand (3) zur objektiv ermittelten Zeit in Beziehung gesetzt (4). Abschließend wird diskutiert, inwiefern eine Umsetzung des CI-Wizard in die klinische Routine praktikabel ist (5). 


\subsection{Zusammenfassung der Ergebnisse}

Im folgenden Abschnitt werden die wichtigsten Ergebnisse dieser Arbeit zusammenfassend dargestellt. Eine ausführliche Präsentation und Diskussion der erhobenen Befunde erfolgt in der Publikation.

Soziodemographische Eckdaten: Insgesamt erhoben $n=36$ Probanden der Studie $n=144$ Segmentierungsdatensätze über einen Zeitraum von Januar 2014 - März 2015. Die Teilnehmer wurden entsprechend ihrer Expertise in drei Gruppen eingeteilt (Gruppe I - Oberärzte, Gruppe II - Assistenzärzte, Gruppe III - Studenten). Innerhalb der drei Gruppen gab es keinen signifikanten Unterschied im Geschlechterverhältnis. 87,5\% der teilnehmenden Ärzte waren aus dem Bereich der Hals-, Nasen- und Ohrenheilkunde. Zusätzlich nahmen zwei Radiologen und eine Neurologin an der Studie teil.

Benutzerfreundlichkeit des CI-Wizard: Gemessen an einem Item des Fragebogens durch die Rating-Skala von 1 (,sehr gut") bis 4 (,ungenügend“) ergab die Bedienbarkeit des Programmes eine Einschätzung im Mittel zwischen „sehr gut“ und „mit kleinen Mängeln“. Studenten und Assistenzärzte bewerteten das Bildverarbeitungsprogramm signifikant besser als die Oberärzte.

Genanigkeit: Semiautomatisch segmentierte Strukturen wie der Meatus acusticus externus $(\mathrm{JT}=0.90)$, Ossicula auditus (JT $=0.63)$, Cavum tympani $(\mathrm{JT}=0.87)$, Cochlea $(\mathrm{JT}=0.66)$ und Ductus semicirculares $(\mathrm{JT}=0.61$ ) erreichten hohe Jaccard-Werte. Dies bedeutet eine große Schnittmenge zwischen den Segmentierungsergebnissen der Probanden und des Goldstandards. Geringere Werte erreichten die Segmentierung des Nervus facialis (JT $=0.39$ ) und des Fenestra cochleae $(\mathrm{JT}=0.37)$. Eine geringe Schnittmengentendenz zwischen der Segmentierung der Probanden und des Goldstandards konnte bei der Chorda tympani (JT = 0.11) ermittelt werden.

Zeitaufwand: Gemessen an einer Intervall-Skala im Fragebogen $(1=$,sehr gering“, 2 = „,angemessen“, 3 = „,zu hoch“, 4 = ,viel zu hoch“) wurde der subjektiv eingeschätzte Zeitaufwand zur Ermittlung der Zielansicht als „angemessen“ bewertet. Eine objektive Ermittlung der benötigen Segmentierungszeit für einen Datensatz lag im Mittel bei 9.8 Minuten $( \pm 4.7 \mathrm{~min})$. 


\section{Publikation}

Erschienen in:

European Archives of Oto-Rhino-Laryngology and Head \& Neck, online publiziert (02.09.2016).

An observational, prospective study to evaluate the preoperative planning tool "CI-Wizard" for cochlear implant surgery

Markus Pirlich*1, Mary Tittmann*3, Daniela Franz ${ }^{4}$, Andreas Dietz ${ }^{1,2}$, Mathias Hofer ${ }^{1,2}$ (*geteilte Erstautorenschaft)

${ }^{1}$ Klinik und Poliklinik für Hals-, Nasen- und Ohrenheilkunde Universität Leipzig

Direktor: Prof. Dr. med. A. Dietz.

2 Innovation Center Computer Assisted Surgery (ICCAS)

Universität Leipzig

${ }^{3}$ Eberhard Karls Universität, Tübingen

${ }^{4}$ Fraunhofer Institute for Integrated Circuits (IIS), Erlangen 


\title{
An observational, prospective study to evaluate the preoperative planning tool "CI-Wizard" for cochlear implant surgery
}

\author{
Markus Pirlich ${ }^{1} \cdot$ Mary Tittmann $^{3} \cdot$ Daniela Franz $^{4} \cdot$ Andreas Dietz $^{1,2}$. \\ Mathias Hofer ${ }^{1,2}$
}

Abstract "CI-Wizard" is a new, three-dimensional software planning tool for cochlear implant surgery with manual and semi-automatic algorithms to visualize anatomical risk structures of the lateral skull base preoperatively. Primary endpoints of the study represented the evaluation of the CI-Wizards usability, accuracy, subjectively perceived and objectively measured time in clinical practice. In a period from January 2014 to March $2015, n=36$ participants were included in this study. These members were divided into three groups of equal number $(n=12)$, but different level of experience. Senior doctors and consultants (group 1), residents (group 2) and medical students (group 3) segmented 12 different CTscan data sets of the CI-Wizard (four per participant). In total, $n=144$ data sets were collected. The usability of the CI-Wizard was measured by the given questionnaire with an interval rating scale. The Jaccard coefficient (IT) was used to evaluate the accuracy of the anatomical structures segmented. The subjectively perceived time

M. Pirlich and M. Tittmann contributed equally to this work.

Markus Pirlich

markus.pirlich@medizin.uni-leipzig.de

1 Clinic and Policlinic of Otorhinolaryngology (ENT), University of Leipzig, Liebigstraße 10-14, 04103 Leipzig, Germany

2 Innovation Center Computer Assisted Surgery (ICCAS), University of Leipzig, Leipzig, Germany

3 Eberhard Karls University, Tuebingen, Germany

4 Fraunhofer Institute for Integrated Circuits (IIS), Erlangen, Germany was measured with an interval rating scale in the questionnaire and was compared with the objectively mean measured time (time interact). Across all three groups, the usability of the CI-Wizard has been assessed between 1 ("very good") and 2 ("with small defects"). Subjectively, the time was stated as "appropriate" by questionnaire. Objective measurements of the required duration revealed averages of $t=9.8 \mathrm{~min}$ for creating a target view. Concerning the accuracy, semi-automatic anatomical structures such as the external acoustic canal $(J T=0.90)$, the tympanic cavity $(\mathrm{JT}=0.87)$, the ossicles $(\mathrm{JT}=0.63)$, the cochlea $(\mathrm{JT}=0.66)$, and the semicircular canals $(\mathrm{JT}=0.61)$ reached high Jaccard values, which describes a great match of the segmented structures between the partcipants and the gold standard. Facial nerve $(\mathrm{IT}=0.39)$ and round window $(\mathrm{IT}=0.37)$ reached lower Jaccard values. Very little overlap tendency was found for the chorda tympani $(\mathrm{JT}=0.11)$. This software program represents a further important step in the development of preoperative planning tools in cochlear implant surgery. The study revealed a high level of satisfaction in the usability. The subjectively required time was considered as "appropriate" and the objectively mean measured time was $t=9.8 \mathrm{~min}$ short enough, so that a clinical application seems realistic. Particularly for semiautomatically segmented structures, it represented a good accuracy. For purely manual segmented structures, further improvements are desirable. Finally, this program also provides a good learning tool for medical students and residents to become familiar with the anatomy of the lateral skull base.

Keywords Software planning tools - Cochlear implant surgery $\cdot$ Cochlea $\cdot$ Segmentation $\cdot$ Lateral skull base 


\section{Introduction}

\section{Segmentation in medicine}

For preoperative planning of cochlear implants, a precise idea of the individual anatomy of the lateral skull base, the middle and inner ear is an important requirement. To understand the complex anatomy it can be difficult to evaluate $2 \mathrm{D}$ computer tomography (CT) images singulary $[1,2]$. Three-dimensional reconstructed images allow a facilitate understanding of the patient's anatomy [3-8]. For this reason, many planning tools were developed and improved during the last decades $[6,9]$. Segmentations of the desired anatomical structures function as a basis for these programs [6] and describe a process to determine several objects in an image [10]. Usually, manual segmentation of two-dimensional images is accomplished by trained medical technicians, who sign the contours slice by slice $[6,9,11]$. This process is very time-consuming [6, 9-13] and results may depend on intra- or interobserver variability [6, 9]. For that, many algorithms have been developed to perform computer-assisted segmentation [3, 6, 7, 9]. Integrated semi-automatic algorithms simplify and accelerate the segmentation work even for non-image processing experts $[3,6,7,9]$.

Table 1 gives an overview of selected studies and their results dealing with different image processing software programs and algorithms. This implies the diversity of existing software programs whose aim is to visualize anatomical structures of the middle and inner ear in a threedimensional perspective. The publications show a large margin of the required time starting from $1.5 \mathrm{~min}$ up to $6 \mathrm{~h}$ to develop a target view. There are even just a small number of reconstructions in 3D taken into account in the studies. This results in a conflict between the exact visualization of anatomical risk structures, the required time, and the high technical input for the software, which limits the potential implementation in clinical practice.

Compared to the existing studies, this study tries to evaluate an alternative software program for risk structure segmentation concentrated on usability in daily clinical routine in a large number of segmentations and different levels of experience.

\section{CI-Wizard}

"CI-Wizard" is a new three-dimensional preoperative planning tool for Cochlea Implant surgery with semi-automatic algorithms to visualize anatomical risk structures of the lateral skull base based on CT data. This program tries to build a bridge between medicine and informatics. Wizard (engl. "Magician", "Sorcerer") is a term from the field of computer science and wants to guide and reduce complex configuration labyrinths of computer programs for the specific user [17]. In this case, complex informatic image processes are automatically translated into a simple medical terminology. This helps the user to focus on medical data during the segmentation process. Additionally, the "CI-Wizard" allows the user to change parameters after each step. So the program reaches a balance between flexibility (manual segmentation, semi-automatic corrections) and guidance (semi-automatic algorithms, wizard interaction pattern) in a non-time consuming way.

Cochlear implant $(\mathrm{CI})$

A cochlear implant (CI) provides a therapeutic option for patients with a congenital or acquired severe sensorineural hearing loss due to the cochlea. This specific hearing aid that is inserted into the cochlea intends to improve the hearing and the quality of life of affected patients. The mechanism of the $\mathrm{CI}$ is a stimulation of the cochlear nerve by electrical pulses through the implanted electrode. These stimuli are transmitted to the auditory cortex. Conventional CI surgery is a standardized procedure with different implants available. Nevertheless, for the intraoperatively insertion of the electrode into the cochlea, high-risk structures have to be protected in a limited surgical field [7]. After retroauricular access, subsequent mastoidectomy and posterior tympanotomy, the facial nerve is an important risk structure. Especially the angle of the facial nerve and the chorda tympani is of particular interest. This space called facial recess is approximately $2.5-4 \mathrm{~mm}$ wide $[19,20]$. Further, the fenestra cochleae is another important structure which defines the opening of the round window membrane in terms of cochleostomy and the insertion of a cochlea electrode into the scala tympani as the preferred position [21-23]. Using the "CI-Wizard" anatomical risk structures and landmarks are defined and visualized. Figure 1 displays the relationships of these structures. That aims at a better understanding for the individual anatomic proportions in order to plan the surgery.

\section{Objective}

Aim of this observational prospective study on one hand is to evaluate the usability of the "CI-Wizard" program (1) On the other hand the accuracy of the "CI-Wizard" is examined for individual differences in the segmentation compared to a gold standard (2). In addition, the subjectively perceived time (3) and the objectively measured time (4) will be detected. Finally, the integration into clinical practice for preoperative cochlea implant planning is discussed (5).

\section{然 Springer}




\section{Author's personal copy}

Eur Arch Otorhinolaryngol

Table 1 Segmentation in literature

\begin{tabular}{|c|c|c|c|c|c|}
\hline Study & Planning tool & Segmentation method & $n^{a}$ & Aim of the study & Results \\
\hline $\begin{array}{l}\text { Kisser et al. } \\
\text { (2014) [14] }\end{array}$ & $\begin{array}{l}\text { OsiriX } \\
\text { software }^{\mathrm{b}}\end{array}$ & $\begin{array}{l}\text { 3D-curved multiplanar reconstruction } \\
\text { (MPR) analysis }\end{array}$ & 9 & $\begin{array}{l}\text { Preditiction of cochlear implant } \\
\text { length }\end{array}$ & $\begin{array}{l}\text { Mean time } t=6.1( \pm 3.4) \\
\text { minutes } \\
\text { Accuracy } 0.8( \pm 0.7) \mathrm{mm}\end{array}$ \\
\hline $\begin{array}{l}\text { Gerber et al. } \\
\text { (2013) [7] }\end{array}$ & $\begin{array}{l}\text { QT }^{\mathrm{c}} \\
\text { Open } \\
\text { Inventor }^{\mathrm{d}} \\
\text { DICOM } \\
\text { Toolkit }^{\mathrm{e}} \\
\text { Visualization }^{\text {Visuof }} \\
\text { Toolkit }^{\mathrm{f}} \\
\text { Insight }^{\text {Segmentation }} \\
\text { and } \\
\text { Registration } \\
\text { Toolkit }\end{array}$ & $\begin{array}{l}\text { Marching cube algorithm, Curved planar } \\
\text { reconstruction (CPR) }\end{array}$ & 10 & $\begin{array}{l}\text { Planning a robotically assisted } \\
\text { hearing aid }\end{array}$ & $\begin{array}{l}\text { Mean time } t=15.95 \mathrm{~min} \\
\text { Accuracy } \\
0.15 \pm 0.08 \mathrm{~mm}\end{array}$ \\
\hline $\begin{array}{l}\text { Majdani } \\
\text { et al. } \\
\text { (2009) [15] }\end{array}$ & iPlan $2.6^{\mathbf{h}}$ & $\begin{array}{l}\text { Semi-automatic segmentation with } \\
\text { threshold algorithms and manual } \\
\text { corrections }\end{array}$ & 10 & $\begin{array}{l}\text { Planning a robot-guided } \\
\text { approach for Cl—surgery }\end{array}$ & $\begin{array}{l}\text { Mean time not specified } \\
\text { Accuracy Cochleostomy } \\
\text { deviation } 0.78( \pm 0.29) \\
\text { mm }\end{array}$ \\
\hline $\begin{array}{l}\text { Todt et al. } \\
\text { (2014) [16] }\end{array}$ & ZIBAmira & Not specified & 30 & $\begin{array}{l}\text { Determination of a safe B-FMT } \\
\text { position (Vibrant Bonebridge) }\end{array}$ & $\begin{array}{l}\text { Mean time } t=1.5 \mathrm{~min} \\
\text { Accuracy not specified }\end{array}$ \\
\hline $\begin{array}{l}\text { Rodt et al. } \\
\text { (2002) [3] }\end{array}$ & $\begin{array}{l}\text { 3D-Slicer } \\
\text { Mrx }^{\mathrm{j}} \\
\text { VTK }^{\mathrm{k}}\end{array}$ & $\begin{array}{l}\text { Threshold algorithms combined with } \\
\text { manual segmentation, Marching cube } \\
\text { algorithm }\end{array}$ & 17 & $\begin{array}{l}\text { 3D visualisation of the middle } \\
\text { eat and adjacent structures }\end{array}$ & $\begin{array}{l}\text { Mean time } 6 \mathrm{~h} \\
\text { Accuracy not specified }\end{array}$ \\
\hline
\end{tabular}

${ }^{a} n=$ numbers of teconstructions of anatomical target structures in $3 \mathrm{D}$

b version 4.1,64bit

${ }^{c}$ Digia, Helsinki, Finland

${ }^{d}$ Coin 3D, Kongsberg, Norway

e DCMTK, OFFIS computer science institute, Germany

${ }^{\mathrm{f}}$ VTK, Kitware Inc., USA

ITK, Kitware., USA

${ }^{\text {h }}$ BrainLAB AG, Feldkirchen, Germany

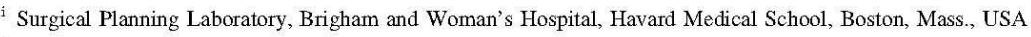

Surgical Planning Laboratory

${ }^{k}$ Visualisation Tool Kit

\section{Materials and methods}

\section{Cooperations}

This data set was collected in cooperation with the University Hospital of Leipzig, the Fraunhofer Institute of Erlangen (IIS) and the University of Tuebingen in the design of a prospective trial.

\section{CI-wizard}

In this study, the evaluated CI-Wizard embodies an image processing software program, which has been developed by the above mentioned cooperation partners for preoperative cochlea implant planning. The CI-Wizard operates with manual and semi-automatic algorithms to facilitate and to visualize the segmentation of eight anatomical risk structures of the external, middle, and inner ear. Figure 2 demonstrates the CI-Wizard sequences. With the optional correction mode (yellow), the CI-Wizard user is able to refine and undo the result after each segmentation step (e.g., grow/shrink). Necessary corrections are shown in red.

A wizard graphical user interface (gui) contains detailed instruction with a four-part view (Fig. 3) to show the stored CT images in an axial, sagittal, and coronal perspective together with a $3 \mathrm{D}$ visualization. After each step, the user 
Fig. 1 Segmentation of anatomical risk structures and landmarks for CI planning. 1

Meatus acusticus externus (AC),

2 Ossicles (OS), 3 Tympanic

cave (TC), 4 Facial nerve (NF),

5 Chorda tympani (NC), 6

Round window (RW), 7

Cochlea (CO), 8 Semicircular

Canals (SC)
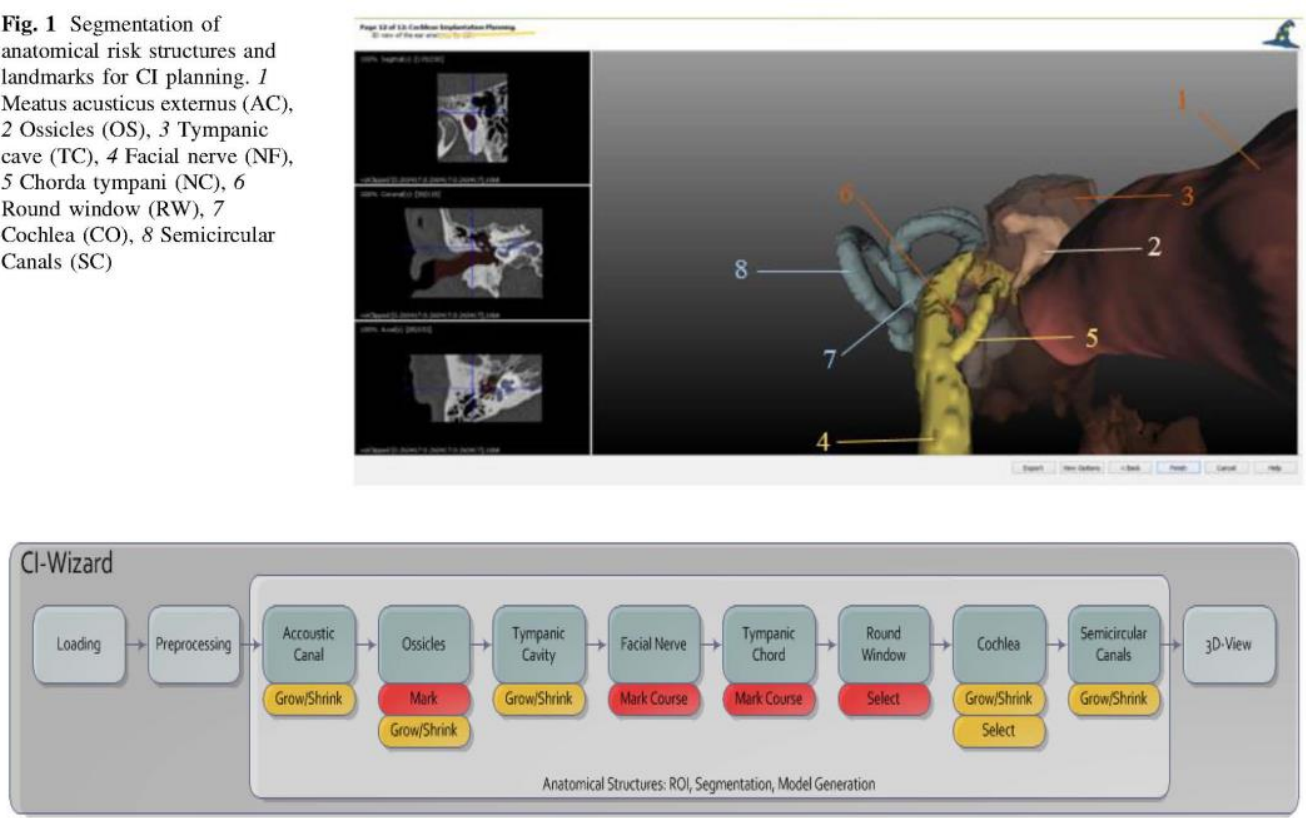

Fig. 2 CI-wizard segmentation pipeline (gray) with the optional (yellow) and necessary (red) correction possibilities

Fig. 3 Four-part view of CI-

Wizard. 1 page and anatomical structure, 2 instruction, 3

correction mode, 4 navigation buttons

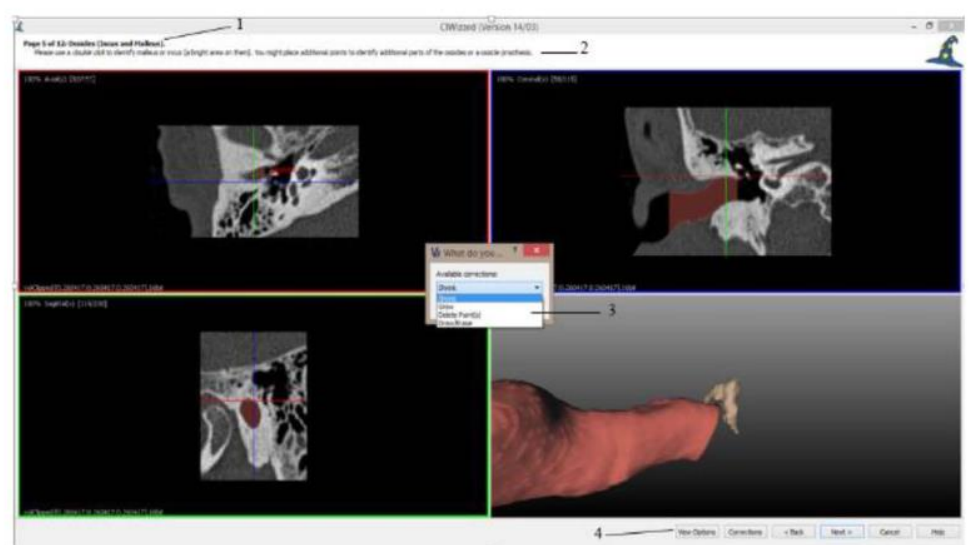

receives immediate visual feedback of the segmented structure.

\section{Data sets}

This study is based on $n=12$ spiral CT-scan patient data (six left ears and six right ears), which were uploaded in the
CI-Wizard program and segmented in detail by the participants. The average age of the patients was 64 years $( \pm 16)$. Six records contained minor anatomical deviations, e.g., missing ossicles, a partial ossicular replacement prosthesis (PORP), or an acoustic canal stenosis while the other six records showed normal findings. The mean resolution of the CT data sets was $0.24 \mathrm{~mm}^{2}$ pixel $( \pm 0.07)$

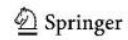


with a layer spacing of $0.4 \mathrm{~mm}( \pm 0.29)$ in the axial plane. The CT datasets were cut off by an average of $7.5 \times 10^{6}$ voxels $\left( \pm 4.4 \times 10^{6}\right)$ and coated a medium volume of $77.9 \mathrm{~cm}^{3}( \pm 20.4)$.

\section{Study participants}

In a period from January 2014 to March 2015, $n=36$ participants were included in this study. These members were divided into three groups, each with $n=12$ participants. Senior doctors and consultants (group 1), residents (group 2), and medical students (group 3) each segmented four different data sets of the CI-Wizard (per participant). In total, $n=144$ data sets were collected. It was noted that all the participants of each group had the same order, the same level of difficulty, and a standardized instruction for carrying out the study. As a result, the groups were comparable (Fig. 4). Ahead of segmentation, every participant received exactly the same instruction for using the software program by the study leader following a standardized protocol.

\section{Questionnaire}

To capture and quantify a subjective measure in terms of quality of segmentation and the usability in dealing with the CI-wizard program, a questionnaire was developed. After the segmentation, the participants were asked to fill out this questionnaire. Initially, socio-demographic data (e.g., age, specific profession) and the experience level were requested. In the main part of the questionnaire, the quality of segmentability has been detected. Each named anatomical structure was rated using a scale from 0 to 5

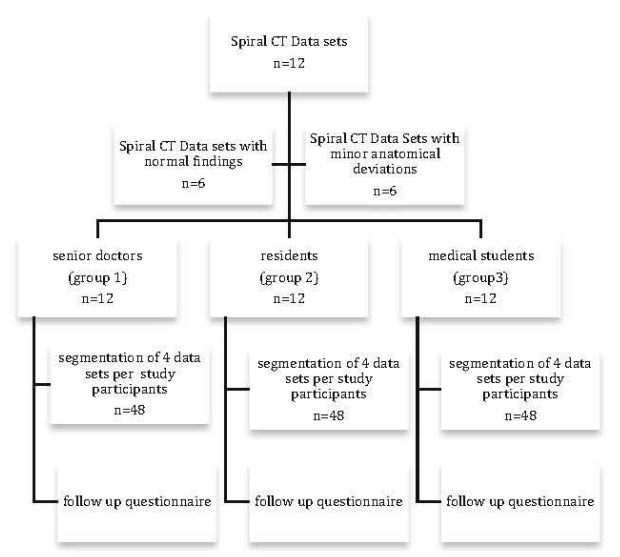

Fig. 4 Flow chart of the study design
( $" 0=$ not at all", " $5=$ very good"). Further, an evaluation of the general usability of the program and the subjectively estimated time expansion followed using a rating scale. Suggestions and requirements for the Cl-wizard program could be proclaimed at the end in a free text form.

\section{Accuracy and time}

In contrast to the subjective analysis, the CI-wizard program itself allowed an objective quantification of two other important parameters.

On the one hand, an objective measurement of time (ms) was carried out. At this point, a distinction between "total time" and "time interact" was made. The latter means the indeed active segmentation time, while the total time also includes software loadings or downtimes during the data collection. To record "time interact", the software gatherd the runtime of the segmentation pipelines "time pipelines" and subtracted it from the "total time" ( $T_{\text {interact }}=$ $\left.T_{\text {total }}-T_{\text {pipelines }}\right)$.

On the other hand, an important focus was on assessing the accuracy of the CI-wizard. For this purpose, a goldstandard segmentation was created as a template for an optimal segmentation of a data set and for each structure. This pattern was compared with each segmented structure of a participant. For the definition of the segmentation accuracy, the Jaccard index [24] (Figs. 5, 6) was used. It is also known as the well-established Tanimoto coefficient or coefficient of community $[25,26]$. This index describes the similarity of two sets while dividing the number of common elements by the size of the common area. The Jaccard index assumes a non-dimensional value between " 0 " and "1". The value " 1 " stands for the highest possible common area and marks an accurate segmentation with respect to the gold standard. The value " 0 ", however, does not correspond to the common intersection and describes an incorrect segmentation of the participant.

\section{Statistical analysis}

To analyse the statistical data, the program JMP 11_2 was used. Categorical data are reported as absolute and relative frequencies (proportions and percentage). Continuous data are expressed as mean $( \pm \mathrm{SD})$. Multifactorial analyses of variance $(F)$ were used to compare the differences between

$$
J\left(\mathrm{~S}_{\left.P_{\text {art }}, \mathrm{S}_{\mathrm{GS}}\right)}=\frac{\mid \text { SPart } \cap S G S \mid}{\mid \text { SPart } \cup S G S \mid}\right.
$$

Fig. 5 Jaccard index 
Fig. 6 Visualization of the options for a Jaccard value

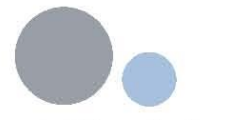

a $\mathbf{J}\left(\mathrm{S}_{\text {Part }}, \mathrm{S}_{\mathrm{GS}}\right)=0$

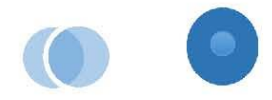

b $\mathbf{J}\left(\mathrm{S}_{\text {Part }}, \mathrm{S}_{\mathrm{GS}}\right)>0<1$

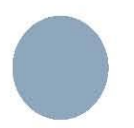

c $\mathrm{J}\left(\mathrm{S}_{\text {Part }}, \mathrm{S}_{\mathrm{GS}}\right)=1$

the groups $1-3$. A nominal $p$ value $<0.05$ was considered as being statistical significant.

\section{Results}

\section{Sociodemographic data}

In total, $n=144$ CT-scan data sets were segmented by $n=36$ participants, which were divided into three groups of equal number $(\mathbf{n}=12)$. The participant characteristics are summarized in Table 2.

$87.5 \%$ of the participating physicians were from the field of ENT $(n=21)$. Two radiologists and one participant of the neurology department were the remaining subjects.

\section{Subjective parameters}

\section{Evaluation of the CI-Wizard usability}

The usability of the CI-Wizard (Fig. 7) was measured by the given questionnaire with an interval rating scale from 1 ("very good") to 4 ("insufficient"). A univariate ANOVA (analysis of variance) revealed a significant effect for this item in reference to the study groups $[F(2.36)=3.82$, $p=0.03$ ]. Students (Group III) rated the usability best $(M=1.17, \mathrm{SD}=0.39)$, followed by the Residents (Group

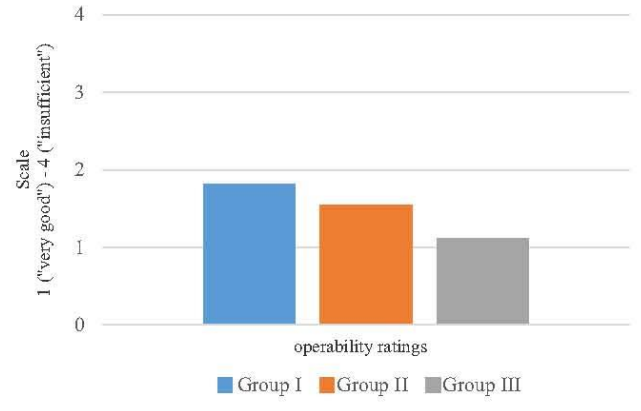

Fig. 7 CI-Wizard usability rating

II, $M=1.55, \quad \mathrm{SD}=0.69$ ), and Seniors (Group I, $M=1.82, \mathrm{SD}=0.60)$.

Evaluation of the segmentation quality

The study participants evaluated the quality how well the $n=8$ anatomical structures $(\mathrm{AC}=$ acoustic canal, $\mathrm{OS}=$ ossicles, $\mathrm{TC}=$ tympanic cavity, $\mathrm{NF}=$ facial nerve, $\mathrm{NC}=$ chorda tympani, $\mathrm{RW}=$ round window, $\mathrm{CO}=\mathrm{co}-$ chlea/vestibule/inner ear canal, $\mathrm{SC}=$ semicircular canal) can be segmented in the questionnaire with an interval rating scale from 1 ("very good") to 5 ("not at all"). Figure 8 depicts the subjective segmentation quality

Table 2 Participant characteristics

\begin{tabular}{|c|c|c|c|c|}
\hline & Group 1 (seniors) & Group 2 (residents) & Group 3 (students) & $p$ \\
\hline$N$ (performed data sets) & $12(48)$ & $12(48)$ & $12(48)$ & \\
\hline Age $M \pm \mathrm{SD}$ (years) & $39 \pm 6.1$ & $29 \pm 2.2$ & $27 \pm 4.2$ & $0.00^{3}$ \\
\hline Gender (female/male) & $2 / 10$ & $6 / 6$ & $7 / 5$ & $N S^{b}$ \\
\hline Ear interventions/year $(n)^{\mathrm{c}}$ & 32 & 0 & 0 & \\
\hline Experience with CT data ${ }^{\text {d }}$ & Extensive & Moderate & None & \\
\hline Experience with ear anatomy ${ }^{d}$ & Extensive & Moderate & Moderate & \\
\hline Experience with medicalcomputer software ${ }^{\text {d }}$ & Moderate & Moderate & None & \\
\hline Experience with segmentation $^{\mathrm{d}}$ & Moderate & Moderate & None & \\
\hline
\end{tabular}

${ }^{a}$ Statistical analysis performed with the one-way analysis of variance

${ }^{b}$ Statistical analysis performed with the Chi-square test, NS not significant

${ }^{c}$ Minor surgical procedures such as paracentesis and ventilation tubes were excluded

"Items measured by the questionnaire (median) were each rated by the variables 1 ("extensive"), 2 ("moderate"), and 3 ("none") 


\section{Author's personal copy}

Eur Arch Otorhinolaryngol

Fig. 8 CI-Wizard segmentation quality ratings (per group und per structure). $A C$ acoustic canal, $O S$ ossicles, $T C$ tympanic cavity, $N F$ facial nerve, $N C$ chorda tympani, $R W$ round window, $C O$ cochlea, vestibule, inner ear canal, $S C$ semicircular canal

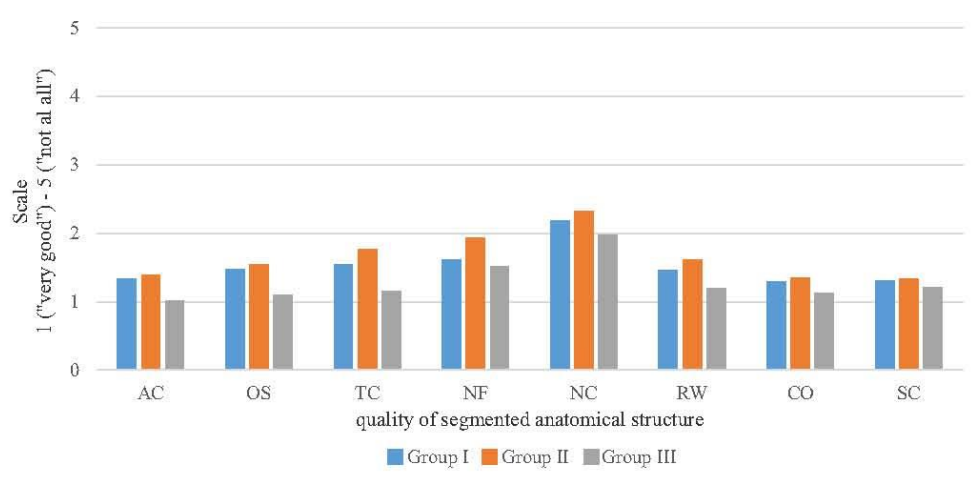

ratings per group and per structure. All anatomical structures were assessed between 1 ("very good") and 2 ("with minor errors")

The univariate ANOVA showed no significant differences regarding the segmentation assessment of the anatomical structures in intergroup comparison, except for the round window $[F(2.36)=3.47, p=0.046]$. On average, the Residents reviewed the segmentability of the round window significantly worse $(M=1.69, \mathrm{SD}=0.65)$ than the Seniors $(M=1.57, \mathrm{SD}=0.43)$ and worse than the Students $(M=1.18, \mathrm{SD}=0.25)$.

\section{Evaluation of subjective required time}

Using our questionnaire with an interval scale for this item (1 = "low", 2 = "adequate", 3 = "high", 4= "too high"), the medium Wizard time rating was "adequate" (Group I: $M=2.0, \mathrm{SD}=0.63$, Group II: $M=1.91$, $\mathrm{SD}=0.70$, Group III: $M=1.67, \mathrm{SD}=0.49$ ). The univariate ANOVA revealed no significant effect for this factor in the assessment between the three groups $[F(2,36)=0.92, p=0.41]$.

\section{Objective parameters}

Evaluation of objective required time

Across all groups, the average runtime of the CI-Wizard was $T_{\text {interact }}=9.8 \mathrm{~min}( \pm 4.7 \mathrm{~min})$ to segment a record. Based on Fig. 9, it can be seen that the Seniors needed more time $(M=11 \pm 5 \mathrm{~min})$ than the Residents $(M=9 \pm 5 \mathrm{~min})$ and the Students $(M=8 \pm 3 \mathrm{~min})$. The univariate ANOVA revealed no significant value for this factor $[F(2,36)=0.93, p=0.40]$.

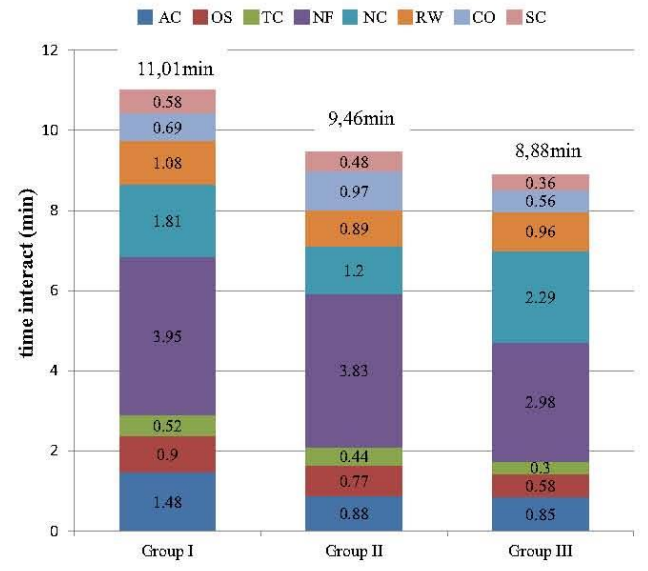

Fig. 9 Time interact in minutes (per dataset)

\section{Evaluation of Accuracy}

The statistical analysis to data on the accuracy of the CIWizard program was carried out by calculating the Jaccard coefficient. For each segmented structure, the averages have been distributed based on the respective groups in accordance to Table 3 .

There has been a high correspondence between the segmentation of the study participants and the gold standard for the anatomical structures of the extemal acoustic meatus (AC) and the tympanic cavity (TC). Ossicles (OS), cochlea $(\mathrm{CO})$, and semicircular canals (SC) showed relatively high overlaps between the participants and the gold standard. Facial nerve (NF) and round window (RW) 


\section{Author's personal copy}

Eur Arch Otorhinolaryngo

Table 3 Objective evaluation of segmentation accuracy using the Jaccard Index

\begin{tabular}{lllllllll}
\hline & AC & OS & TC & NF & NC & RW & CO & SC \\
\hline Seniors & 0.92 & 0.68 & 0.89 & 0.38 & 0.11 & 0.48 & 0.68 & 0.64 \\
Residents & 0.90 & 0.61 & 0.87 & 0.37 & 0.07 & 0.31 & 0.64 & 0.62 \\
Students & 0.89 & 0.61 & 0.85 & 0.42 & 0.15 & 0.34 & 0.66 & 0.58 \\
Summary & 0.90 & 0.63 & 0.87 & 0.39 & 0.11 & 0.37 & 0.66 & 0.61 \\
& SD $=0.01$ & SD $=0.04$ & SD $=0.02$ & SD $=0.02$ & SD $=0.04$ & SD $=0.09$ & SD $=0.02$ & SD $=0.03$ \\
\hline
\end{tabular}

$A C$ acoustic canal, $O S$ ossicles, $T C$ tympanic cavity, $N F$ facial nerve, $N C$ chorda tympani, $R W$ round window, $C O$ cochlea, vestibule, inner ear canal, $S C$ semicircular canals

reached lower Jaccard values. Little tendency for overlap was found for the chorda tympani (NC).

\section{Discussion}

Three-dimensional software planning tools for the lateral skull base have become popular. Many advantages such as the better preoperative presentation of the individual anatomical site $[3-6,18]$, the reduction of surgery complications $[7,16]$ or the increase of the surgeon's spatial awareness [6, 7, 27] and experience level [15] were described in several studies. These tools are continuously improved $[3,6,7,12,16,27,28]$. The given study evaluated the CI-Wizard as a modern software tool for the three-dimensional visualization of risk structures of the lateral skull base in a clinical setting.

Usability The usability has been assessed across the three groups between "very good" and just "with small defects". These good results are mainly justified by the fact that integrated semi-automatic algorithms were used in this software program, which simplify the segmentation work even for non-experienced $[3,6,7,9]$. The plain structure of the program with clear work instructions probably also leads to this assessment of the usability. According to the literature of Rodt et al. [3], the use of different colors for various anatomical structures and a simultaneous view in an axial, sagittal, and coronal dimension led in addition to a better visualization of the situs in this study. Furthermore, the direct conversion of $2 \mathrm{D}$ images into a $3 \mathrm{D}$ visualization helps to detect and understand the relationship of the different ear structures [3]

Time exposure Subjectively, the time was stated as "appropriate" by questionnaire. Objective measurements of the required duration revealed averages of $n=9.8 \mathrm{~min}$ ( $\pm 4.7 \mathrm{~min}$ ) for creating a target view. This is in line with results from other studies. According to the study of Kisser et al. [14], a preoperative prediction of the best cochlear implant electrode length requires $n=6.1 \mathrm{~min}(\mathrm{SD}=3.4)$. It was considered as "not time-consuming" and applicable in clincal routine [14]. Gerber et al. [7] described a surgical planning tool for robot-assisted hearing aid implantation which needed less then $n=20 \mathrm{~min}$ for one ear. Also in this tool, semi-automatic algorithms improved the time rate to determine a target view. In comparison, a pure manual segmentation requires much more time $[6,10,12,13]$. Referring to the presented study, the highest amount of time was even measured in the manual segmentation of the nerves compared to the other semi-automatic structures (Fig. 9). Rodt et al. [3] for instance needed up to $n=6 \mathrm{~h}$ per case by the help of the software tool "3D Slicer". Thus, it can be noted that the "CI-Wizard" quickly leads to the desired target view. A clinical application of the CI-Wizard seems to be considerable.

Accuracy Due to small safety margins during the surgery, the accuracy of the segmentation of anatomical risk structures is highly important [7]. In contrast to the study of Noble and Dawant [31], which used the Dice similarity coefficient to evaluate the accuracy, we applied the wellestablished Jaccard coefficient [25, 29]. It could be shown that anatomical structures such as the acoustic canal (AC) or the tympanic cavity (TC) reach high values. In these cases, there was a great match of the segmented structure between the participants and the gold standard. Particularly, low scores were detected for the chorda tympani (NC) and the facial nerve (NF). This discrepancy seems to be multifactorial. The most common explanation for this fact is the different size of anatomical structures. The facial nerve (NF) is a tubular structure of about $1.5 \mathrm{~mm}(\sim 5$ voxels) and the chorda tympani of approximately $0.3 \mathrm{~mm}$ $(\sim 1$ voxel) in diameter $[28,31]$. The external acoustic canal (AC), however, is an anatomical structure of approximately $20-30 \mathrm{~mm}$ in length and can be clearly discriminated by a high difference in hounsfield units (air vs. bone) and indicates a higher probability of area overlap. Minimal shifts in the segmentation of the nerves compared to the gold standard cause greater effects in the Jaccard value. Further, the nerves are difficult to segment, due to the lower contrast to nearby structures (much lower difference in hounsfield units) and the large interpatient variations $[28,31]$, especially in a reduced CT resolution setting. Even for experienced surgeons, it is sometimes not 
easy to follow the course of these nerves from slice to slice [28]. In this study, semi-automatic segmentations (AC, OS, $\mathrm{TC}, \mathrm{CO}, \mathrm{SC}$ ) showed more accurate results than the manual procedures (NF, NC). This is consistent with results from Noble et al. [28]. They present a new technique that integrates an atlas-based approach with a minimum cost path finding algorithm to segment the facial nerve and the chorda tympani automatically. They showed that the automatic borders surrounded the nerves were generally smoother and more accurate than the manual one [28] Therefore, it can be determined that an automatic segmentation of the nerves would be beneficial for a next version of the CI-Wizard. Furthermore, it can be profitable to combine these algorithms with magnetic resonance imaging (MRI), because the different sections of the facial nerve can be pictured to very high resolution $[3,6,28]$. In line with this, Noble and Dawant [31] developed successfully an algorithm for the optic nerves on the data base of CT-scan and MRI in a further study. The contemplation of the round window (RW) in this context takes a special position because the CI-Wizard showed each participant several candidate regions. Following, the user could select the target structure by own anatomical knowledge. In this instance, the univariate ANOVA pointed a significant effect $[F(2,36)=3.469, p=0.046]$ Accordingly, Group I (Seniors) with the highest professional and anatomical expertise reached better Jaccard values than the Residents (Group 2) and Students (Group 3). Especially the oval and round window were often confounded by Residents and Students. At this point, integrated anatomical landmarks (e.g., the stapes) could help to minimize these errors in future software programs. Finally, a positive correlation of subjective evaluations of segmented risk structures and objective measured Jaccard indices can be recognized. The good evaluation of the acoustic canal (AC) coincides with high Jaccard indices of all groups. Similar correlations arise for the structures OS, $\mathrm{CO}$, and SC (ossicles, cochlea/inner ear canal, semicircular canals). In this regard, the chorda tympani (NC) was rated the worst, reaching the lowest Jaccard values. The round window (RW) was significantly worse evaluated by Residents and Students, probably due to lack of anatomical knowledge for this structure in the CT. A discrepancy of ratings were obtained for the structures tympanic cavity (TC) and facial nerve (NF). The segmentability of these landmarks were evaluated almost the same, but the TC achieved much better objective results than the NF. This again shows that semi-automatic segmentation lead to better results than manual ones.

Limitations Limitations of this study were, first, that there have been no serious pathologies (e.g., infections, tumors, congenital deformities) in the used records. Thus, no valid statements concerning the functionality of the "CI-Wizard" can be taken in pathological conditions. This should be the subject of investigations in follow-up studies. Second, it would be desirable to specify the anatomical conditions in the three-dimensional target view in millimeters. To check the accuracy, it was therefore only possible to use the Jaccard index. Moreover, the gold standard was defined as an independent segmentation of $n=2$ experts (senior physician of ENT and radiology). These segmentations, though gathered independently of our experts showed high similarities. Still, one might increase in subsequent studies the number of experts to define a more accurate gold standard.

Clinical usability The clinical usability of a software program correlates with the ratio of real-life conditions and the quality of a predicted surgical situation. In addition, a preoperative segmentation has to be a non-time consuming procedure. It is to be discussed, whether manual or (semi-) automatic segmentations of anatomical structures are better compatible to be integrated into clinical practice. Various studies showed that the manual segmentation of $2 \mathrm{D}$ images often requires hours, even when carrying out by trained persons $[10,12,13]$. In contrast, the work of Noble et al. [12] compared the results of fully automatic segmentations of anatomical structures of the middle and inner ear with very accurate results (e.g., $0.3 \mathrm{~mm}$ mean deviation in the identification of the facial nerve or the chorda tympani) within less than $n=10 \mathrm{~min}$ per patient scan. Due to these facts, automatic segmentations seem to be significantly more profitable for the clinical routine. Nevertheless, it is important that the surgeon is involved with its professional expertise in the preoperative planning process. Thus, it can be better evaluated whether (to be segmented) structures are over-, or more importantly, less represented [7]. At that point, the CI-Wizard tries to fill this gap and finds a compromise. By using semi-automatic algorithms, the program is clinically feasible with a planning period of $n=9 \mathrm{~min}$ and the surgeon can verify the segmentation in every step. Moreover, the CI-Wizard reached good results in this clinical study with respect to the accuracy of the investigated structures.

Prospects In further studies it will be interesting to evaluate serious pathologies (e.g., infections, tumors, or ear deformities) and CT scans of children with the CIWizard. Furthermore, it would be desirable to integrate a tool to span a distance in millimeter between several anatomical structures. Finally, following the authors' observations the CI-Wizard seems to be a suitable instrument for teaching, learning, and conceiving lateral skul base anatomy. Another interesting aspect is to deliver the cochlear length as an accurate measured value to choose the corresponding electrode, preoperatively, to reduce intraoperative trauma. 


\section{Conclusion}

In summary, this software program represents a further step in the development of preoperative planning tools in the cochlear implant surgery for clinical practice. For all groups $(n=3)$, a high level of satisfaction in the usability was seen. On average, the subjectively required time was considered as "appropriate". The objectively meanly measured time was $n=9 \mathrm{~min}$, so that a clinical application seems realistic. Particularly for semi-automatically segmented structures, the CI-Wizard could represent a good accuracy. For purely manual segmented structures such as the facial nerve and the chorda tympani, further improvements are desirable $[7,28,30]$. Finally, this program also provides a good learning tool for Students and Residents to become familiar with the anatomy of the lateral skull base.

\section{Compliance with ethical standards}

Conflict of interest All authors declare no conflicts of interest.

Informed consent Informed consent was obtained from all individual participants included in the study.

\section{References}

1. Howard JD, Elster AD, May JS (1990) Temporal bone: three dimensional CT. I. Normal anatomy, techniques and limitations. Radiology 177:421-425

2. Ali QM, Ulrich C, Becker H (1993) Three-dimensional CT of the middle ear and adjacent structures. Neuroradiology 35:238-241

3. Rodt Ratiu, Becker Bartling, Kacher Anderson, Jolesz Kikinis (2002) 3D visualisation of the middle ear and adjacent structures using reconstructed multi-slice CT datasets, correlating 3D images and virtual endoscopy tot he 2D cross-sectional images. Neuroradiology 44:783-790

4. Howard JD, Elster AD, May JS (1990) Temporal bone: three-dimensional CT. II. Pathologic alterations. Radiology 177:427-430

5. Hermans R, Marchal G, Feenestra L, Baert AL (1995) Spiral CT of the temporal bone: value of image reconstruction at submillimetric table increments. Neuroradiology 37:150-154

6. Ferreira A, Gentil F, Tavares JM (2014) Segmentation algorithms for ear image data towards biomechanical studies. Comp Methods Biomech Bio Eng 17:888-904

7. Gerber N, Bell B, Gavaghan K, Weisstanner C, Caversaccio M, Weber S (2014) Surgical planning tool for robotically assisted hearing aid implantation. Int J CARS 9:11-20

8. Marro A, Bandukwala T, Mak W (2015) Three-dimensional printing and medical imaging: a review of the methods and applications. Curr Probl Diagn Radiol 112-117

9. Ma Zhen, Tavares JM, Jorge RN, Mascarenhas T (2010) A review of algorithms for medical image segmentation and their applications to the female pelvic cavity. Comp Methods Biomech Bio Eng 13(2):235-246

10. Anderson JR, Barrett SF (2007) A quantitative comparison between manual segmentation and threshold-based segmentation of CLSM recorded images. Biomed Sci Instrum 43:290-295

11. Sartoretti-Schefer S, Kollias S, Wichmann W, Valavanis A (1998) T2-weighted three-dimensional fast spin-echo MR in inflammatory peripheral facial nerve palsy. Am J Neuroradiol 19:491-495
12. Noble JH, Dawant BM, Warren FM, Labadie RF (2009) Automatic identification and $3 \mathrm{D}$ rendering of temporal bone anatomy. Otol Neurotol 30(4):436-442

13. Braun K, Böhnke F, Stark T (2012) Three-dimensional representation of the human cochlea using micro-computed tomography data: presenting an anatomical model for further numerical calculations. Acta Otolaryngol 132:603-613

14. Kisser U, Ertl-Wagner B, Hempel JM, Müller J, D'Anastasi S, Anderson-Kisser C, Laubender R, Stelter K, Braun C, Pomschar A (2014) High-resolution computed tomography-based length assessments of the cochlea - an accuracy evaluation. Acta OtoLaryngogica 134:1011-1015

15. Majdani O, Rau T, Baron S, Eilers H, Baier C, Heimann B, Ortmaier T, Bartling S, Lenarz T, Leinung M (2009) A robotguided minimally invasive approach for cochlear implant surgery: preliminary results of a temporal bone study. Int J Proc Comp Assist Radiol Surg 4(5):475-486

16. Todt I, Lamecker H, Ramm H, Ernst A (2014) A computed tomographic data-based vibrant bonebridge visualization tool. Cochlear Implants Int 15(1):72-74

17. Frauenberger C, Stockman T, Putz V, Höldrich, R (2005) Mode independent interaction pattern design. Ninth International Conference on Information Visualisation (IV'05):24-30

18. Schubert O, Sartor K, Forsting M, Reisser C (1996) Three-dimensional computed display of otosurgical operation sites by spiral CT. Neuroradiology 38:663-668

19. Bielamowicz SA, Coker NJ, Jenkins HA et al (1988) Surgical dimensions of the facial recess in adults and children. Arch Otolaryngol Head Neck Surg 114:534-537

20. Su WY, Marion MS, Hinojosa R et al (1982) Anatomical measurements of the cochlear aqueduct, round window membrane, round window niche and facial recess. Laryngoscope 92:483-486

21. Adunka OF, Radeloff A, Gstoettner WK et al (2007) Scal tympani cochleostomy II: topographie and histology. Laryngoscope 117:2195-2200

22. Roland PS, Wright CG, Isaacson B (2007) Cochlear implant electrode insertion: the round window revisited. Laryngoscope 117:1397-1402

23. Schipper J, Klenzer T, Aschendorff A et al (2004) Navigationcontrolled cochleostomy. -Is an improvement in the quality of results for chochlear implant surgery possible? HNO 52:329-335

24. Jaccard P (1912) The distribution of the flora in the alpin zone. New Phytol 11(2):37-50

25. Todeschini R, Consonni V, Xiang H, Holliday J, Buscema M, Willett P (2012) Similarity coefficients for binary chemoinformatics data: overview and extended comparison using simulated and real data sets. J Chem Inf Model 52:2884-2901

26. Alroy J (2015) A new twist on a very old binary similarity coefficient. Ecology 96(2):575-586

27. Jun BC, Song SW, Cho JE, Park CS, Lee DH, Chang KH, Yeo SW (2005) Three-dimensional reconstruction based on images from spiral high-resolution computed tomography of the temporal bone: anatomy and clinical appilcation. J Laryngol Otol 119(9):693-698

28. Noble JH, Warren FM, Labadie RF, Dawant BM (2008) Automatic segmentation of the facial nerve and the chorda tympani in CT images using spatially dependent feature values. Am Assoc Physicists Med 35(12):5375-5384

29. Hubálek Z (1982) Coefficients of association and similarity, based on binary (presence-absence) data: an evalutation. Biol Rev 57:669-689

30. Kanitsar A, Fleischmann D, Wegenkittl R, Felkel P, Gröller ME (2002) CPR-curved planar reformation. IEEE Visual VIS 2002:37-44

31. Noble JH, Dawant BM (2011) An atlas-navigated optimal medial axis and deformable model algorithm (NOMAD) for segmentation of the optic nerves and chiasm in MR and CT images. Med Image Anal 15(6):877-884 


\section{Zusammenfassung}

Publikationspromotion zur Erlangung des akademischen Grades Dr. med. an der Medizinischen Fakultät der Universität Leipzig

„Cochlea-Implantat-Chirurgie: Eine prospektive Studie zur Evaluation eines dreidimensionalen, präoperativen Bildverarbeitungsprogrammes (CI-Wizard)“

eingereicht von Mary Tittmann (09/2017)

angefertigt am Universitätsklinikum Leipzig AöR,

Klinik und Poliklinik für Hals-, Nasen-, Ohrenheilkunde

Direktor: Prof. Dr. med. Andreas Dietz

Betreuer: $\quad$ Prof. Dr. med. Andreas Dietz

Dr. med. Mathias Hofer

Dr. med. Markus Pirlich

Bildverarbeitungsprogramme zur dreidimensionalen Visualisierung von anatomischen Risikostrukturen zur präoperativen Planung eines Cochlea Implantates einzusetzen, stieß in den letzten Jahrzehnten auf großes Interesse und erlangte zunehmende Bedeutung in der Cochlea Chirurgie (Marrow et al., 2015; Ferreira et al., 2012; Schubert et al., 1995). Die Integrierung geeigneter Algorithmen zeigt, wie in Tabelle 1 oder in dem Review von Ferreira et al. (2012) dargestellt, eine hohe Vielfalt. Mit Blick auf die Anwendung solcher Programme im klinischen Alltag werden hohe Anforderungen an die Genauigkeit einerseits und an den möglichst geringen Zeitaufwand andererseits gestellt. Ein neu entwickeltes Bildverarbeitungsprogramm „CI-Wizard“ versucht diese Lücke zwischen den komplexen informatischen Prozessen und den Ansprüchen der Mediziner zu schließen. Dafür nutzt das Programm eine Kombination von semiautomatischen Algorithmen und manueller Segmentierung. Acht verschiedene anatomische Risikostrukturen der lateralen Schädelbasis werden teils manuell und teils semiautomatisch vom Benutzer segmentiert. Zu diesen Strukturen gehören: (1) Meatus acusticus externus; (2) Ossicula auditus; (3) Cavum tympani; (4) Nervus facialis; (5) Chorda tympani; (6) Fenestra cochleae; (7) Cochlea; (8) Ductus semicirculares. 
Das Ziel der vorliegenden Arbeit war es, dieses Programm hinsichtlich verschiedener primärer Endpunkte zu evaluieren und anschließend zu diskutieren, inwiefern die Einbeziehung in den klinischen Alltag realistisch erscheint. Einerseits sollte die Benutzerfreundlichkeit des Bildverarbeitungsprogrammes CI-Wizard untersucht werden. Andererseits soll die Genauigkeit der individuellen Segmentierungen der Probanden mit einem Goldstandard verglichen werden. Zudem wird die objektiv ermittelte Zeit dem subjektiv empfunden Zeitaufwand gegenübergestellt.

Hierzu wurden insgesamt $n=144$ Datensätze von $n=36$ Probanden in dem Zeitraum von Januar 2014 bis März 2015 segmentiert. Jeder Proband erhielt im Voraus eine standardisierte Anleitung zur Bedienung des CI-Wizards (siehe Anlage A). Je zwölf Probanden und deren Segmentierungsergebnisse wurden drei Gruppen mit unterschiedlicher fachlicher Expertise zugeordnet (Gruppe I - Oberärzte, Gruppe II - Assistenzärzte, Gruppe III - Studenten). Zur Erfassung der subjektiven Wahrnehmung des Zeitaufwandes und zur Einschätzung der Bedienbarkeit erhielten alle Probanden einen standardisierten Fragbogen (siehe Anlage B). Das objektive Zeitmaß konnte durch den CI-Wizard selbst detektiert werden. Zur Bestimmung der Genauigkeit wurden die individuell segmentierten Ergebnisse der Probanden dem Goldstandard gegenübergestellt und durch die Bestimmung des Jaccard Index objektiviert (Jaccard, 1912; Alroy 2015).

Benutzerfreundlichkeit des CI-Wizard: Über alle Gruppen hinweg wurde im Fragebogen das Item „Bedienbarkeit“ zwischen „sehr gut“ und „,mit kleinen Mängeln“ bewertet. Dieses sehr gute Ergebnis scheint besonders in der klaren Struktur des Programmes und der Integrierung semiautomatischer Algorithmen begründet. Wie unter anderem in der Arbeit von Gerber et al. (2013) oder Noble et al. (2009) beschrieben, vereinfachen automatisierte Algorithmen die Segmentierungsarbeit. Auch die Verwendung von unterschiedlichen Farben für jede Struktur vereinfachen das Verständnis des anatomischen Situs (Rodt et al., 2002).

Genanigkeit: Zur Evaluation der Genauigkeit verwendeten wir den Jaccard Index (Jaccard, 1912; Alroy 2015). Er beschreibt eine dimensionslose Größe zwischen O und 1, wobei letzteres eine maximale Übereinstimmung zwischen dem individuell segmentierten Ergebnis in Bezug auf den Goldstandard darstellt. Zusammenfassend fiel auf, dass semiautomatisch segmentierte anatomische Strukturen höhere Jaccard Indices erreichten, als manuell segmentierte und bestätigte damit die Ergebnisse einer Studie von Noble et al. (2008). Die Segmentierung des Meatus acusticus externus $(\mathrm{JT}=0.90)$, Ossicula auditus $(\mathrm{JT}=0.63)$, Cavum tympani $(\mathrm{JT}=0.87)$, Cochlea $(\mathrm{JT}=$ 0.66) und Ductus semicirculares (JT $=0.61)$ zeigten eine hohe Übereinstimmung mit dem 
Goldstandard. Geringere Werte konnten für den Nervus facialis (JT $=0.39$ ) und die Chorda tympani $(\mathrm{JT}=0.11)$ ermittelt werden. Eine Integrierung automatischer Algorithmen zur Segmentierung der Nerven nach dem Vorbild von Noble et al. (2008) beispielsweise könnte für eine nächste Version des CI-Wizard profitabel sein und ein genaueres Ergebnis erzielen. Aufgrund einer schlechten Auflösung einiger CT-Datensätze fiel es teilweise schwer die Nerven korrekt zu verfolgen. Auch dies könnte die Ungenauigkeiten der Segmentierungsergebnisse erklären. In der aktuellen Literatur wurden Algorithmen auf Basis von MRT-Bildern beschrieben (Noble \& Dawant, 2011). Dies könnte im Sinne einer Weiterentwicklung des CI-Wizards in weiteren Studien Beachtung finden.

Zeitaufwand: Das Ziel bei der Entwicklung des CI-Wizard bestand unter anderem darin, ein neues Bildverarbeitungsprogramm zur präoperativen Planung von Cochlea Implantaten zu entwickeln, das im klinischen Alltag praktikabel und exakt arbeitet. Eine Anforderung an das Programm besteht in Form eines möglichst geringen Zeitaufwandes. Die Analyse des Fragebogens zur Erfassung der subjektiven Wahrnehmung des Zeitaufwandes zeigte, dass dieser im Mittel als „angemessen“ beurteilt wurde. Objektive Messungen ergaben im Mittel 9.8 Minuten ( \pm 4.7 min) zur Entwicklung der dreidimensionalen Zielansicht. In der aktuellen Literatur wird für die Bestimmung einer präoperativen Cochlea Implantatlänge über einen Zeitaufwand von 6.1 Minuten berichtet. Dies wird als nicht zeitaufwändig und praktikabel für die klinische Routine bewertet (Kisser et al., 2014) und bestätigt auch unsere Einschätzung. Im Vergleich zur hauptsächlichen Benutzung von manuellen Algorithmen, sind semiautomatische Algorithmen maßgeblich für den geringen Zeitaufwand verantwortlich und werden in der Literatur als weiterer positiver Aspekt angegeben (Ferreira et al., 2014; Anderson \& Barret, 2007). Dies können wir mit unserer Zeitmessung unter Verwendung semiautomatischer Algorithmen bestätigen.

In Zusammenschau unserer Ergebnisse kann das neu entwickelte Bildverarbeitungsprogramm CI-Wizard als ein erfolgversprechendes, klinisch anwendbares, präoperatives Planungswerkzeug im Rahmen der CI-Chirurgie bewertet werden. Die Benutzerfreundlichkeit wurde von den Probanden als positiv bewertet und der Zeitaufwand im Durchschnitt als „,angemessen“ eingeschätzt. Mit einem objektiven Zeitmaß von $9.8 \min ( \pm 4.7$ min) scheint eine Umsetzung im klinischen Alltag als realistisch. Strukturen, die auf Basis von semiautomatischen Algorithmen segmentiert wurden, erreichten eine hohe Genauigkeit in Bezug zum Goldstandard. Die Segmentierung insbesondere des Nervus facialis und der Chorda tympani könnte in einer folgenden Softwareversion verbessert werden. 


\section{Literaturverzeichnis}

Alroy J (2015) A new twist on a very old binary similarity coefficient. Ecology, 96 (2), 575-586.

Anderson JR, Barrett SF (2007) A quantitative comparison between manual segmentation and threshold-based segmentation of CLSM recorded images. Biomed Sci Instrum, 43, 290 295.

Bichey BG, Hoversland JM, Wynne MK, Miyamoto RT (2002) Changes in Quality of Life and the Cost-Utility Associated with Cochlear Implantation in Patients with Large Vestibular Aqueduct Syndrome. Otology \& Neurotology, 23, 323-327.

Bielamowicz SA, Coker NJ, Jenkins HA, Igarashi M (1988) Surgical dimensions of the facial recess in adults and children. Arch Otolaryngol Head Neck Surg, 114, 534-537.

Clark GM, Tong YC, Bailey QR, Black RC, Martin LF, Millar JB, O`Loughlin BJ, Patrick JF, Pyman BC (1978) A Multiple-Electrode Cochlear Implant. J. Otolaryng. Soc. Ausatral., 4 (3), 208-212.

Ferreira A, Gentil F, Tavares JM (2014) Segmentation algorithms for ear image data towards biomechanical studies. Computer Methods in Biomechanics and Biomedical Engineering, 17, 888-904.

Franz D (2016) Wizard-based Image Processing for the Life Sciences. PhD thesis, University of Erlangen-Nuernberg.

Gerber N, Bell B, Gavaghan K, Weisstanner C, Caversaccio M, Weber S (2013) Surgical planning tool for robotically assisted hearing aid implantation. Int J Comput Assist Radiol Surg, 7(1), 133-136.

Jaccard P (1912) The distribution of the flora of the alpin zone. New Phytol, 11, 37-50.

Kisser U, Ertl-Wagner B, Hempel JM, Müller J, D`Anastasi, Schrötzlmair, Anderson-Kisser C, Laubender R, Stelter K, Braun C, Pomschar A (2014) High-resolution computed 
tomography-based length assessments of the cochlea - an accuracy evaluation. Acta OtoLaryngogica, 134, 1011-1015.

Majdani O, Rau T, Baron S, Eilers H, Baier C, Heimann B, Ortmaier T, Bartling S, Lenarz T, Leinung M (2009) A robot-guided minimally invasive approach for cochlear implant surgery: preliminary results of a temporal bone study. International Journal Proc Comp Assist Radiol Surg, 4 (5), 475-486.

Marro A, Bandukwala T, Mak W (2015) Three-Dimensional Printing and Medical imaging: A Review of the Methods and Applications. Curr Probl in Diagn Radiol, 112-117.

Mudry A, Mills M (2013) The Early History of the Cochlear Implant. A Retrospective. JAMA Otolaryngol Head Neck Surg, 139 (5), 446-453.

Noble JH, Warren FM, Labadie RF, Dawant BM (2008) Automatic segmentation of the facial nerve and the chorda tympani in CT images using spatially dependent feature values. American Association of Physicists in Medicine, 35 (12), 5375-5384.

Noble JH, Dawant BM, Warren FM, Labadie RF (2009) Automatic identification and 3D rendering of temporal bone anatomy. Otol Neurotol, 30 (4), 436-442.

Noble JH, Dawant BM. (2011) An atlas-navigated optimal medial axis and deformable model algorithm (NOMAD) for segmentation of the optic nerves and chiasm in MR and CT images. Med Image Anal, 15 (6), 877-884.

Rodt T, Ratiu P, Becker H, Bartling S, Kacher DF, Anderson M, Jolesz FA, Kikinis R (2002) 3D visualisation of the middle ear and adjacent structures using reconstructed multi-slice CT datasets, correlating 3D images and virtual endoscopy tot he 2D cross-sectional images. Neuroradiology, 44, 783-790.

Roland PS, Wright CG, Isaacson B (2007) Cochlear implant electrode insertion: the round window revisited. Laryngoscope, 117, 1397-1402.

Schubert O, Sartor K, Forsting M, Reisser C (1996) Three-dimensional computed display of otosurgical operation sites by spiral CT. Neuroradiology, 38 (7), 663-668. 
Sim JH, Puria S (2008) Soft tissue morphometry of the malleus-incus complex from micro-CT imaging. J Assoc Res Otolaryngol, 9 (1), 5-21.

Stjernholm C (2003) Aspects of temporal bone anatomy and pathology in conjunction with cochlear implant surgery. Acta radiologica 430, 2-15.

Su WY, Marion MS, Hinojosa R, Matz GJ (1982) Anatomical measurements of the cochlear aqueduct, round window membrane, round window niche and facial recess. Laryngoscope, 92, 483-486.

Suetens P, Bellon E, Vandermeulen D, Smet M, Marchal G, Nuyts J, Mortelmans L (1993) Image segmentation: methods and applications in diagnostic radiology and nuclear medicine. Eur J Radiol, 17 (1), 14-21.

Tidwell Jenifer (2005) Designing Interfaces. 1. Auflage: O`Reilly Verlag, 54-58.

Todt I, Lamecker H, Ramm H, Ernst A (2014) A computed tomographic data-based vibrant bonebridge visualization tool. Cochlear Implants Int, 15 (1), 72-74.

Zenner HP (2002) Beethovens Taubheit: „Wie ein Verbannter muß ich leben“. Dtsch Arztebl, 99 (Heft 42), A 2762-2766.

Zhen Ma, Tavares JM, Jorge RN, Mascarenhas T (2010) A review of algorithms for medical image segmentation and their applications to the female pelvic cavity. Computer Methods in Biomechanics and Biomedical Engineering, 13(2), 235-246. 


\section{Anlagen}

\section{A Standardisierte Anleitung zur Instruktion der Probanden}

Jeder Proband soll nach einer standardisierten Anleitung zur Bedienung des Softwareprogrammes „CI-Wizard“ selbstständig Risikostrukturen der lateralen Schädelbasis an vier verschiedenen Datensätzen segmentieren.

\section{Schritt}

Der Studienleiter gibt einen Überblick über die Thematik und Fragestellungen der Studie.

\section{Schritt}

Abbildung 1: Abkürzung „KK“ zur standardisierten Anleitung von Datensatz, B

Die Anleitung erfolgt anhand Datensatz B. Dieser wird mit „KK“ gekennzeichnet (Abbildung 1) und fließt nicht in die Auswertung der Ergebnisse ein.

\begin{tabular}{l} 
CIWizard - Study Version \\
This software is not intended to diagnose, treat, cure, or prevent any disease. \\
For scientific use please give the first letters of your surname and name. <br >For Daniela Franz it would be FD. \\
\hline $\mathrm{KK} \mid$ \\
\hline
\end{tabular}

\section{Schritt}

Der allgemeine Aufbau des CI-Wizard wird erläutert und die. vier Fenster (axialer, sagitaler und coronarer Schnitt, 3D-Darstellung, siehe Abbildung 2 und 3) werden demonstriert. Durch Schieben des Cursors ist eine gleichzeitige Verschiebung in allen Ebenen möglich. Durch Scrollen mit der mittleren Maustaste wird die Ansicht vergrößert. Durch Anklicken der 3D-Darstellung mit der linken Maustaste ist diese räumlich drehbar. Mittels den Befehlen „View Options $\rightarrow$ Slices in 3D View ON/Off“" ist es möglich, das 3D Modell in CT Ebene integriert darzustellen. Dies ist in Abbildung 4 dargestellt. Anschließend werden dem Probanden Korrekturmöglichkeiten beispielsweise das Vergrößern („Corrections $\rightarrow$ Grow“) oder das Verkleinern („Corrections $\rightarrow$ Shrink") einer Struktur vorgestellt.

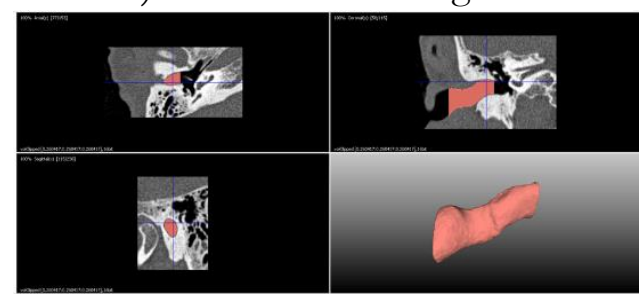

Abbildung 2: Vier-Fensteransicht

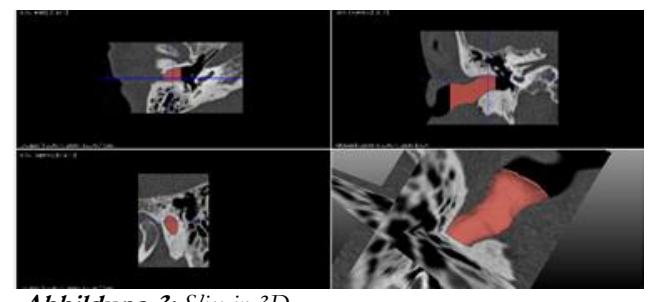

Abbildung 3: Slice in 3D 


\section{Schritt}

Schrittweise Segmentierung in acht Schritten:

1. Meatus acusticus externus

2. Ossicula auditus (Incus, Malleolus)

3. Cavitas tympani

4. Nervus facialis

5. Chorda tympani

6. Runde Fensternische

7. Cochlea

8. Bogengänge

Der dafür erforderliche Befehl zur Auswahl der Struktur ist jeweils „Shift und linker Mausklick“. abschließendes Berechnen des dreidimensionalen Modells zur Darstellung von Risikostrukturen.

Chronologische Darstellung der Segmentierung in den nachfolgenden Abbildungen (4 bis 9). Besonderer Hinweis: Die Nerven müssen von zentral nach peripher segmentiert werden. Dabei besteht die Möglichkeit Korrekturen vorzunehmen. Man kann sowohl den ersten („Corrections $\rightarrow$ delete last point“), als auch alle Punkte („Corrections $\rightarrow$ delete all points) löschen. Darüber hinaus muss der Proband darauf hingewiesen werden, dass die erforderliche Zeit gestoppt wird.

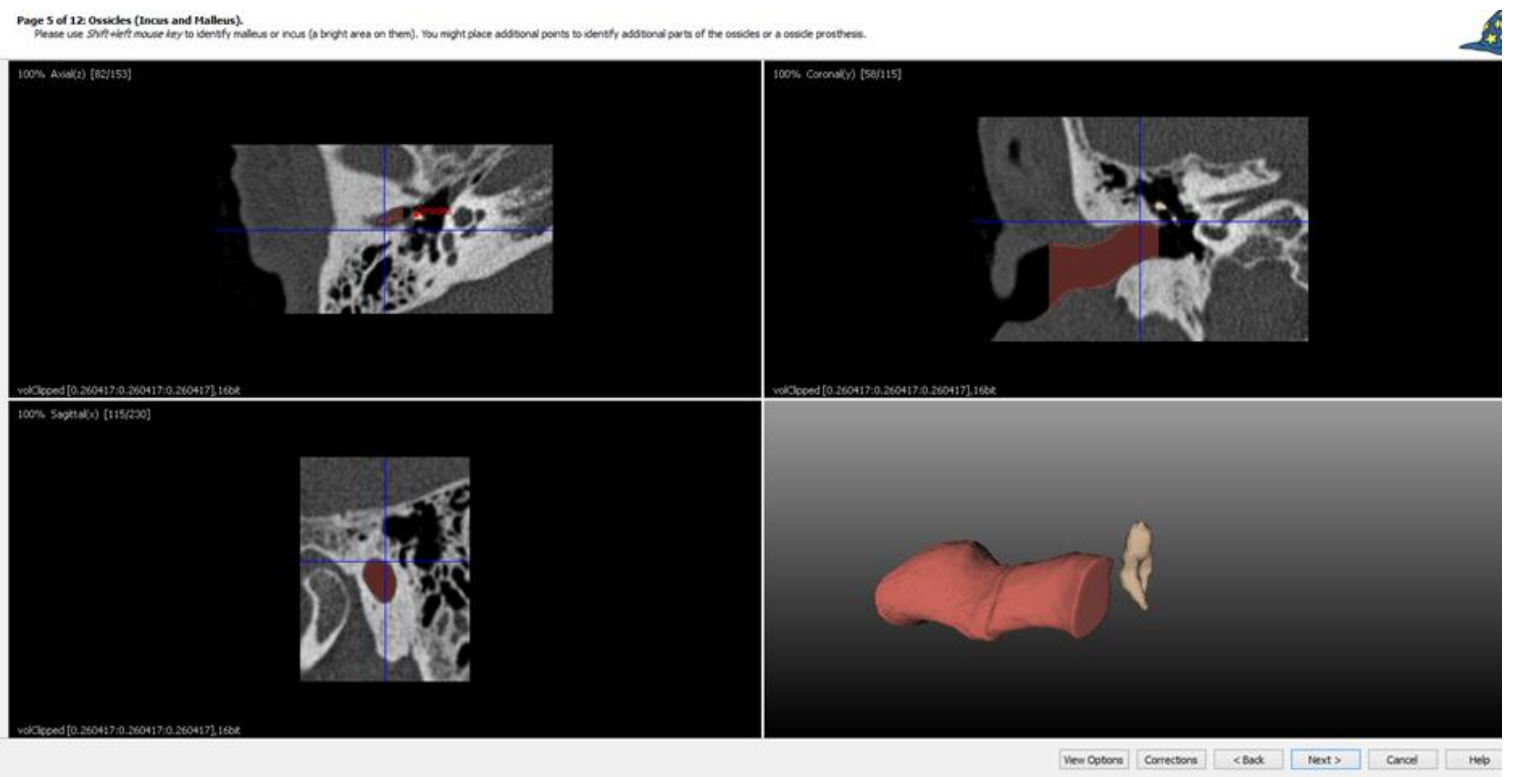

Abbildung 4: 1. Segmentierung Meatus acusticus externus, 2. Segmentierung Ossicula auditus 


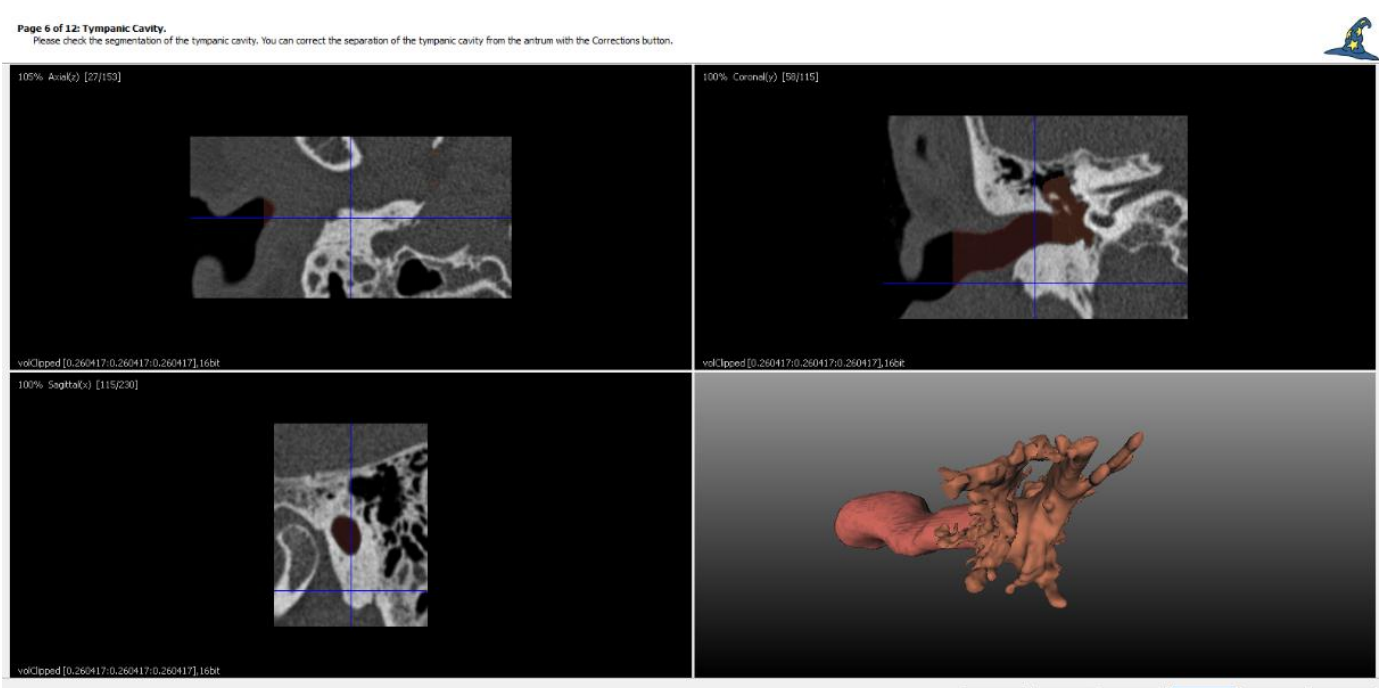

Abbildung 5: 3. Segmentierung der cavitas tympani

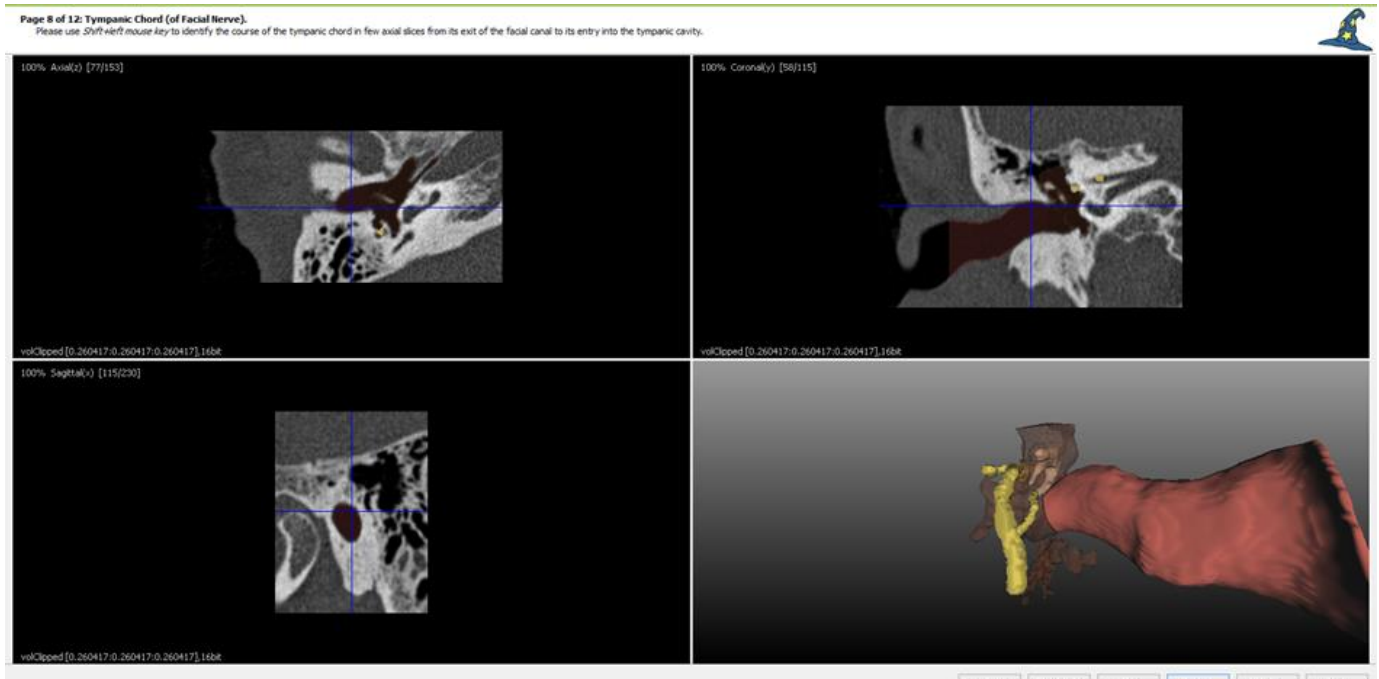

Abbildung 6: 4. Segmentierung des Nervus facialis, 5. Segmentierung der Chorda tympani

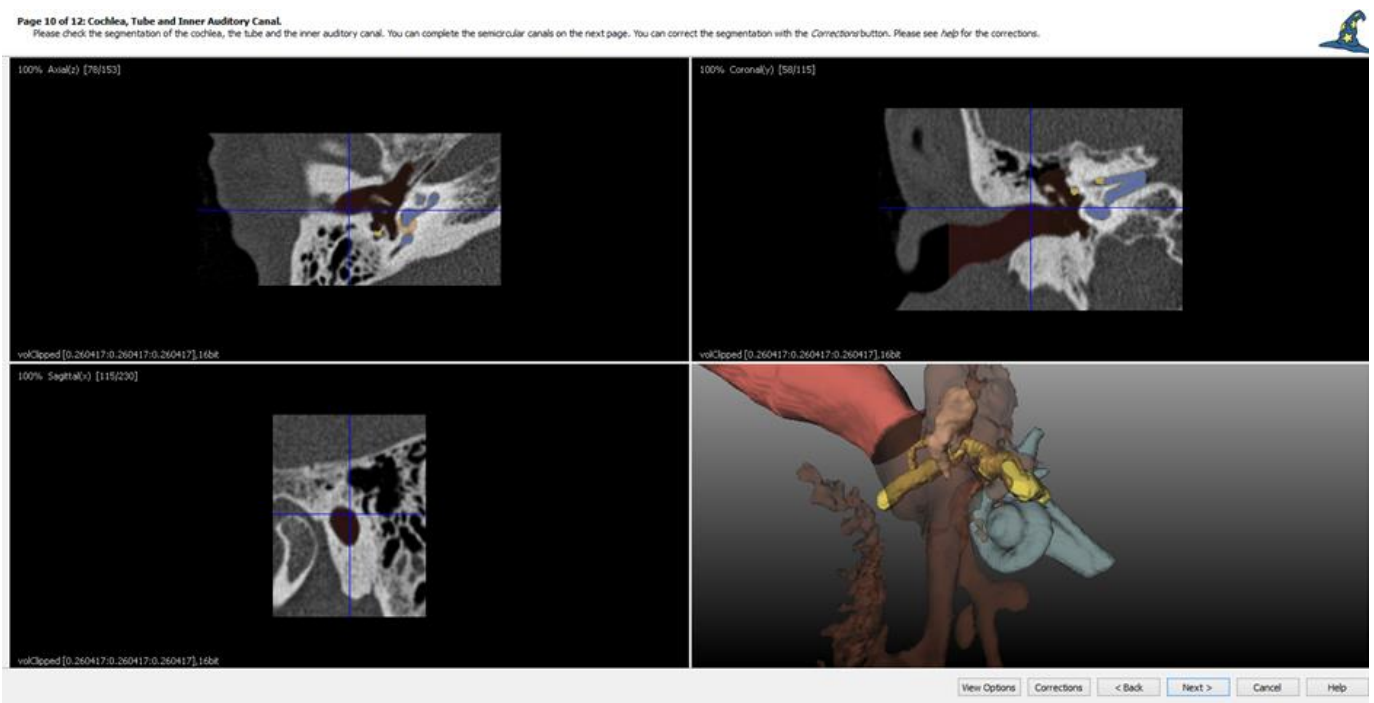

Abbildung 7: 6. Segmentierung der runden Fensternische, 7. Segmentierung der Cocblea 


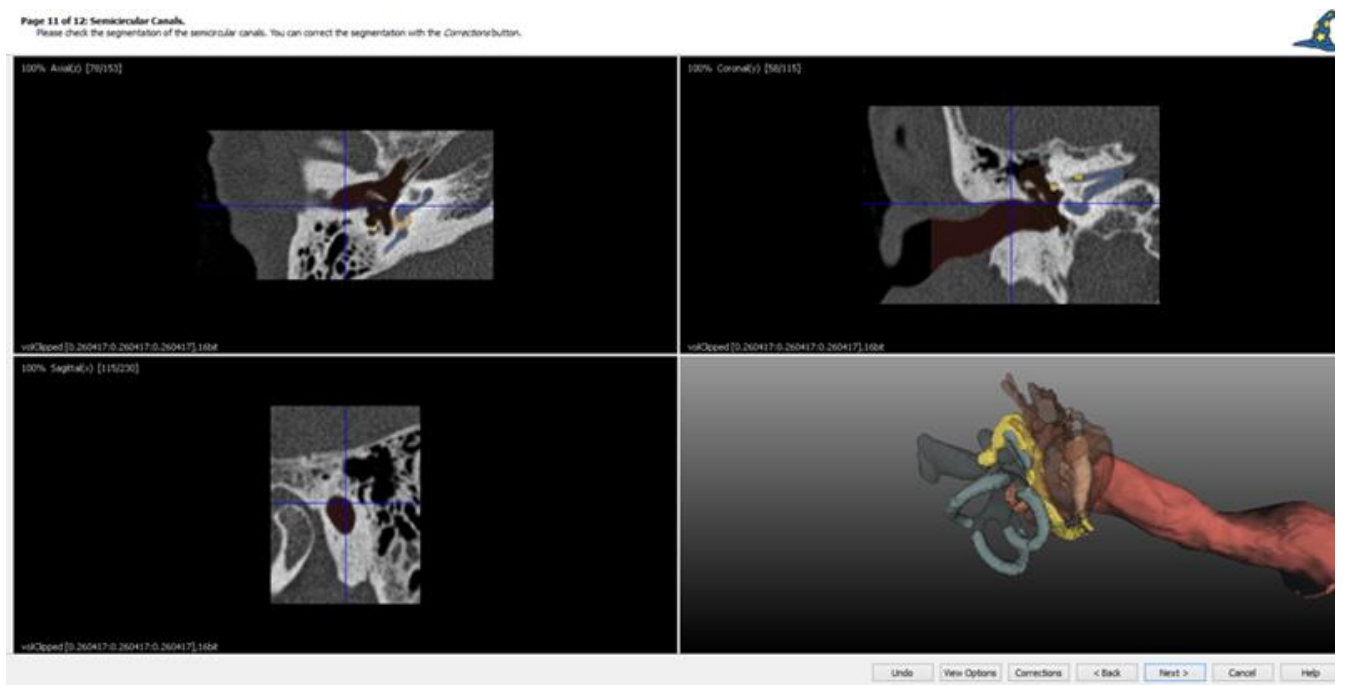

Abbildung 8: 8. Segmentieren der Bogengänge

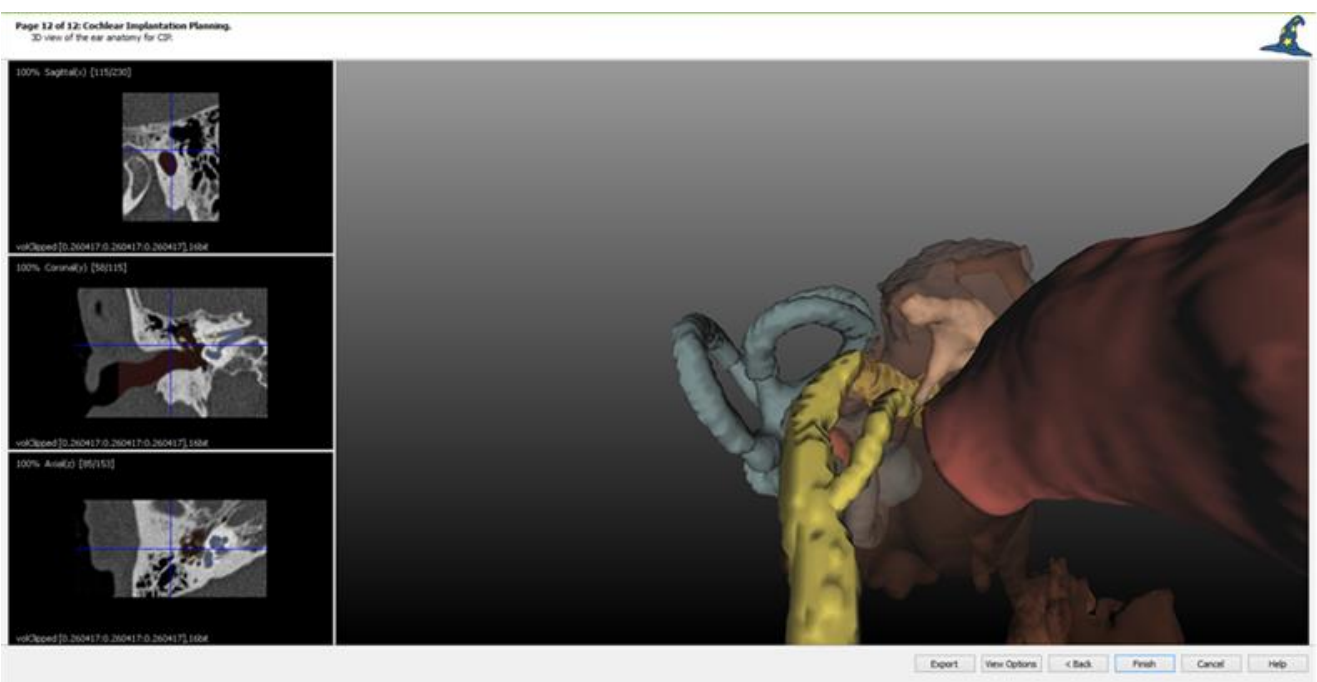

Abbildung 9: Zielansicht der segmentierten Risikostrukturen zur Planung eines Cochlea Implantates 


\section{B Fragebogen zur Evaluation des CI Wizard}

Probandennummer:

Probandenkürzel: (wird vom Studienleiter eingetragen)

Vornamens) (erster Buchstaben Ihres Namens und

Alter:

O 20-29

O 30-39

$040-49$

$050-59$

$0>60$

Geschlecht:

O männlich

O weiblich

Berufsgruppe:

O Radiologie

O HNO-Chirurgie

O Informatik

0

Ich bin seit Jahren in meinem Gebiet tätig

Falls sie HNO-Chirurg sind:

Ich führe Ohr (außer Parazentese/Paukendrainage)-chirurgische Eingriffe im Jahr durch.

Hiervon Cochlea Implantationen (für Assistenzärzte nur bedingt zutreffend).

Meine Erfahrung mit...

$\begin{array}{llll}\text { CT Daten: } & \text { O umfangreich } & \text { O mäßig } & \text { O keine } \\ \text { Anatomie des Ohres: } & \text { O umfangreich } & \text { O mäßig } & \text { O keine } \\ \begin{array}{l}\text { Medizinische } \\ \text { Computersoftware: }\end{array} & \text { O umfangreich } & \text { O mäßig } & \text { O keine } \\ \text { Segmentierung: } & \text { O umfangreich } & \text { O mäßig } & \text { O keine }\end{array}$

Im Folgenden bitten wir Sie 4 Datensätze mit dem Cl-Wizard zu bearbeiten und zu jedem Datensatz Fragen zu beantworten. Im Anschluss finden Sie auf Seite 4 noch allgemeine Fragen zu Bedienbarkeit und Zeitbedarf.

Öffnen Sie nun bitte den Cl-Wizard, geben Ihr Kürzel ein und wählen den ersten Datensatz aus. 


\section{Datensatz 1:}

Wie schätzen Sie Ihren Zeitaufwand für diese Segmentierung ein? O hoch O neutral O gering

Wie gut konnten Sie die anatomischen Strukturen mit dem Cl-Wizard segmentieren:

$\begin{array}{llllll}\text { Meatus acust. internus } & \text { O sehr gut } & \text { O mit kleinen Mängeln } & \text { O mit Mängeln } & \text { O ungenügend } & \text { O gar nicht } \\ \text { Meatus acust. externus } & \text { O sehr gut } & \text { O mit kleinen Mängeln } & \text { O mit Mängeln } & \text { O ungenügend } & \text { O gar nicht } \\ \text { Ossikelkette } & \text { O sehr gut } & \text { O mit kleinen Mängeln } & \text { O mit Mängeln } & \text { O ungenügend } & \text { O gar nicht } \\ \text { Cavum tympani } & \text { O sehr gut } & \text { O mit kleinen Mängeln } & \text { O mit Mängeln } & \text { O ungenügend } & \text { O gar nicht } \\ \text { Nervus facialis } & \text { O sehr gut } & \text { O mit kleinen Mängeln } & \text { O mit Mängeln } & \text { O ungenügend } & \text { O gar nicht } \\ \text { Chorda tympani } & \text { O sehr gut } & \text { O mit kleinen Mängeln } & \text { O mit Mängeln } & \text { O ungenügend } & \text { O gar nicht } \\ \text { Rundfensternische } & \text { O sehr gut } & \text { O mit kleinen Mängeln } & \text { O mit Mängeln } & \text { O ungenügend } & \text { O gar nicht } \\ \text { Cochlea } & \text { O sehr gut } & \text { O mit kleinen Mängeln } & \text { O mit Mängeln } & \text { O ungenügend } & \text { O gar nicht } \\ \text { Ductus semicirculares } & \text { O sehr gut } & \text { O mit kleinen Mängeln } & \text { O mit Mängeln } & \text { O ungenügend } & \text { O gar nicht }\end{array}$

Welche Pathologien oder Besonderheiten konnten Sie in diesem Datensatz feststellen? Waren diese auch in der Segmentierung sichtbar? sichtbar $\mathrm{O}$ in den Schichten $\mathrm{O}$ in 3D $\mathrm{O}$ nein sichtbar $\mathrm{O}$ in den Schichten $\mathrm{O}$ in 3D $\mathrm{O}$ nein sichtbar $\mathrm{O}$ in den Schichten $\mathrm{O}$ in 3D $\mathrm{O}$

nein

\section{Datensatz 2:}

Wie schätzen Sie Ihren Zeitaufwand für diese Segmentierung ein? O hoch O neutral $\mathrm{O}$ gering

Wie gut konnten Sie die anatomischen Strukturen mit dem Cl-Wizard segmentieren:

$\begin{array}{llllll}\text { Meatus acust. internus } & \text { O sehr gut } & \text { O mit kleinen Mängeln } & \text { O mit Mängeln } & \text { O ungenügend } & \text { O gar nicht } \\ \text { Meatus acust. externus } & \text { O sehr gut } & \text { O mit kleinen Mängeln } & \text { O mit Mängeln } & \text { O ungenügend } & \text { O gar nicht } \\ \text { Ossikelkette } & \text { O sehr gut } & \text { O mit kleinen Mängeln } & \text { O mit Mängeln } & \text { O ungenügend } & \text { O gar nicht } \\ \text { Cavum tympani } & \text { O sehr gut } & \text { O mit kleinen Mängeln } & \text { O mit Mängeln } & \text { O ungenügend } & \text { O gar nicht } \\ \text { Nervus facialis } & \text { O sehr gut } & \text { O mit kleinen Mängeln } & \text { O mit Mängeln } & \text { O ungenügend } & \text { O gar nicht } \\ \text { Chorda tympani } & \text { O sehr gut } & \text { O mit kleinen Mängeln } & \text { O mit Mängeln } & \text { O ungenügend } & \text { O gar nicht } \\ \text { Rundfensternische } & \text { O sehr gut } & \text { O mit kleinen Mängeln } & \text { O mit Mängeln } & \text { O ungenügend } & \text { O gar nicht } \\ \text { Cochlea } & \text { O sehr gut } & \text { O mit kleinen Mängeln } & \text { O mit Mängeln } & \text { O ungenügend } & \text { O gar nicht } \\ \text { Ductus semicirculares } & \text { O sehr gut } & \text { O mit kleinen Mängeln } & \text { O mit Mängeln } & \text { O ungenügend } & \text { O gar nicht }\end{array}$

Welche Pathologien oder Besonderheiten konnten Sie in diesem Datensatz feststellen? Waren diese auch in der Segmentierung sichtbar? sichtbar $\mathrm{O}$ in den Schichten $\mathrm{O}$ in 3D $\mathrm{O}$ nein sichtbar $\mathrm{O}$ in den Schichten $\mathrm{O}$ in 3D $\mathrm{O}$ nein sichtbar $\mathrm{O}$ in den Schichten $\mathrm{O}$ in 3D $\mathrm{O}$ nein 


\section{Datensatz 3:}

Wie schätzen Sie Ihren Zeitaufwand für diese Segmentierung ein? O hoch O neutral O gering

Wie gut konnten Sie die anatomischen Strukturen mit dem Cl-Wizard segmentieren:

$\begin{array}{llllll}\text { Meatus acust. internus } & \text { O sehr gut } & \text { O mit kleinen Mängeln } & \text { O mit Mängeln } & \text { O ungenügend } & \text { O gar nicht } \\ \text { Meatus acust. externus } & \text { O sehr gut } & \text { O mit kleinen Mängeln } & \text { O mit Mängeln } & \text { O ungenügend } & \text { O gar nicht } \\ \text { Ossikelkette } & \text { O sehr gut } & \text { O mit kleinen Mängeln } & \text { O mit Mängeln } & \text { O ungenügend } & \text { O gar nicht } \\ \text { Cavum tympani } & \text { O sehr gut } & \text { O mit kleinen Mängeln } & \text { O mit Mängeln } & \text { O ungenügend } & \text { O gar nicht } \\ \text { Nervus facialis } & \text { O sehr gut } & \text { O mit kleinen Mängeln } & \text { O mit Mängeln } & \text { O ungenügend } & \text { O gar nicht } \\ \text { Chorda tympani } & \text { O sehr gut } & \text { O mit kleinen Mängeln } & \text { O mit Mängeln } & \text { O ungenügend } & \text { O gar nicht } \\ \text { Rundfensternische } & \text { O sehr gut } & \text { O mit kleinen Mängeln } & \text { O mit Mängeln } & \text { O ungenügend } & \text { O gar nicht } \\ \text { Cochlea } & \text { O sehr gut } & \text { O mit kleinen Mängeln } & \text { O mit Mängeln } & \text { O ungenügend } & \text { O gar nicht } \\ \text { Ductus semicirculares } & \text { O sehr gut } & \text { O mit kleinen Mängeln } & \text { O mit Mängeln } & \text { O ungenügend } & \text { O gar nicht }\end{array}$

Welche Pathologien oder Besonderheiten konnten Sie in diesem Datensatz feststellen? Waren diese auch in der Segmentierung sichtbar? sichtbar $\mathrm{O}$ in den Schichten $\mathrm{O}$ in 3D O nein sichtbar $\mathrm{O}$ in den Schichten $\mathrm{O}$ in 3D $\mathrm{O}$ nein sichtbar $\mathrm{O}$ in den Schichten $\mathrm{O}$ in 3D O

nein

\section{Datensatz 4:}

Wie schätzen Sie Ihren Zeitaufwand für diese Segmentierung ein? O hoch O neutral O gering

Wie gut konnten Sie die anatomischen Strukturen mit dem Cl-Wizard segmentieren:

$\begin{array}{llllll}\text { Meatus acust. internus } & \text { O sehr gut } & \text { O mit kleinen Mängeln } & \text { O mit Mängeln } & \text { O ungenügend } & \text { O gar nicht } \\ \text { Meatus acust. externus } & \text { O sehr gut } & \text { O mit kleinen Mängeln } & \text { O mit Mängeln } & \text { O ungenügend } & \text { O gar nicht } \\ \text { Ossikelkette } & \text { O sehr gut } & \text { O mit kleinen Mängeln } & \text { O mit Mängeln } & \text { O ungenügend } & \text { O gar nicht } \\ \text { Cavum tympani } & \text { O sehr gut } & \text { O mit kleinen Mängeln } & \text { O mit Mängeln } & \text { O ungenügend } & \text { O gar nicht } \\ \text { Nervus facialis } & \text { O sehr gut } & \text { O mit kleinen Mängeln } & \text { O mit Mängeln } & \text { O ungenügend } & \text { O gar nicht } \\ \text { Chorda tympani } & \text { O sehr gut } & \text { O mit kleinen Mängeln } & \text { O mit Mängeln } & \text { O ungenügend } & \text { O gar nicht } \\ \text { Rundfensternische } & \text { O sehr gut } & \text { O mit kleinen Mängeln } & \text { O mit Mängeln } & \text { O ungenügend } & \text { O gar nicht } \\ \text { Cochlea } & \text { O sehr gut } & \text { O mit kleinen Mängeln } & \text { O mit Mängeln } & \text { O ungenügend } & \text { O gar nicht } \\ \text { Ductus semicirculares } & \text { O sehr gut } & \text { O mit kleinen Mängeln } & \text { O mit Mängeln } & \text { O ungenügend } & \text { O gar nicht }\end{array}$

Welche Pathologien oder Besonderheiten konnten Sie in diesem Datensatz feststellen? Waren diese auch in der Segmentierung sichtbar? sichtbar $\mathrm{O}$ in den Schichten $\mathrm{O}$ in 3D $\mathrm{O}$ nein sichtbar $\mathrm{O}$ in den Schichten $\mathrm{O}$ in 3D $\mathrm{O}$ nein sichtbar $\mathrm{O}$ in den Schichten $\mathrm{O}$ in 3D $\mathrm{O}$ nein 
Allgemeine Fragen zum ClWizard:

Wie beurteilen Sie die Bedienbarkeit des Cl-Wizards:

O sehr gut $\quad O$ mit kleinen Mängeln $\quad O$ mit Mängeln $\quad$ ungenügend

Wie beurteilen Sie den Zeitaufwand des Cl-Wizards:

O sehr gering $\quad O$ angemessen $\quad O$ zu hoch $\quad O$ viel zu hoch

Was fanden Sie am Cl-Wizard besonders gut/schlecht:

Was würden Sie sich für den Cl-Wizard noch wünschen:

OA Dr. med. Mathias Hofer

Dr. med. Markus Pirlich

Univ. HNO Uniklinikum Leipzig

Fragebogenentwurf / Softwareentwicklung:

Daniela Franz

Fraunhofer Institut für Integrierte Schaltungen, Erlangen

Doktorandin:

Mary Tittmann

Eberhard-Karls-Universität Tübingen 


\section{Erklärung über die eigenständige Abfassung der Arbeit}

Hiermit erkläre ich, dass ich die vorliegende Arbeit selbstständig und ohne unzulässige Hilfe oder Benutzung anderer als der angegebenen Hilfsmittel angefertigt habe. Ich versichere, dass Dritte von mir weder unmittelbar noch mittelbar eine Vergütung oder geldwerte Leistungen für Arbeiten erhalten haben, die im Zusammenhang mit dem Inhalt der vorgelegten Dissertation stehen, und dass die vorgelegte Arbeit weder im Inland noch im Ausland in gleicher oder ähnlicher Form einer anderen Prüfungsbehörde zum Zweck einer Promotion oder eines anderen Prüfungsverfahrens vorgelegt wurde. Alles aus anderen Quellen und von anderen Personen übernommene Material, das in der Arbeit verwendet wurde oder auf das direkt Bezug genommen wird, wurde als solches kenntlich gemacht. Insbesondere wurden alle Personen* genannt, die direkt an der Entstehung der vorliegenden Arbeit beteiligt waren. Die aktuellen gesetzlichen Vorgaben in Bezug auf die Zulassung der klinischen Studien, die Bestimmungen des Tierschutzgesetzes, die Bestimmungen des Gentechnikgesetzes und die allgemeinen Datenschutzbestimmungen wurden eingehalten. Ich versichere, dass ich die Regelungen der Satzung der Universität Leipzig zur Sicherung guter wissenschaftlicher Praxis kenne und eingehalten habe.

* Die Betreuung dieser Arbeit erfolgte durch Prof. Dr. med. Andreas Dietz, Dr. med Mathias Hofer und Dr. med. Markus Pirlich, Daniela Franz und Gunnar Blumenstock.

Leipzig, den

Mary Tittmann 


\section{Lebenslauf}

PERSÖNLICHE DATEN

Mary Tittmann, geboren am 25. Februar 1988 in Karl-Marx-Stadt, j. Chemnitz

AKADEMISCHE AUSBILDUNG

01.04.2011 - 23.07.2017 Eberhard Karls Universität Tübingen

Studium der Humanmedizin

23.07.2017

Dritter Abschnitt der ärztlichen Prüfung - M3

(Prädikat: ,sehr gut")

03.05.2016

Zweiter Abschnitt der ärztlichen Prüfung - M2

(Prädikat: ,gut")

18.03.2013 Erster Abschnitt der ärztlichen Prüfung - M1

(Prädikat: ,gut')

BERUFSAUSBILDUNG

09/2007 - 09/2010 Medizinische Berufsfachschule am Universitätsklinikum Leipzig

Ausbildung zur staatlich geprüften Hebamme (Prädikat: „,sehr gut")

WISSENSCHAFTLICHER WERDEGANG

Universitätsklinikum Leipzig (AöR), Klinik und Poliklinik für Hals-, Nasen- und Ohrenheilkunde

Anfertigung einer Dissertationsschrift unter Leitung von

Herrn Prof. Dr. med. A. Dietz

Titel: „Cochlea-Implantat-Chirurgie: Eine empirische, prospektive Studie zur Evaluation eines neuen, präoperativen und dreidimensionalen Bildverarbeitungsprogrammes (CI-Wizard)“

TÄTIGKEITEN

05/2016-04/2017 Praktisches Jahr

Universitätsklinikum Tübingen, St. Elisabeth Krankenhaus Leipzig, Sana Klinikum Borna 
05/2015 - 10/2015 Praxis Frau Dr. Kuhn (Gynäkologin, Tübingen)

Tätigkeiten als Hebamme

01/2013 - 08/2015 Universitätsklinikum Tübingen/Neurologie

MTA, Epilepsiemonitoring

09/2010 - 08/2013ＩRK Krankenhaus Chemnitz-Rabenstein

Hebamme im Kreißsaal

$10 / 2006-02 / 2007$

Auslandsaufenthalt in Nepal

Freiwilligendienst beim Nepalesischen Roten Kreuz

Leipzig, den

Mary Tittmann 


\section{Danksagung}

Ich möchte die Gelegenheit nutzen, um mich an dieser Stelle bei all den Menschen zu bedanken, die mich während meiner akademischen Ausbildung unterstützt haben und ohne deren Hilfe dieses Werk nicht hätte vollbracht werden können.

An erster Stelle gilt dieser Dank meinen beiden Betreuern Herrn Dr. med. Mathias Hofer und Herrn Dr. med. Markus Pirlich. Ihnen verdanke ich sowie eine fachlich, als auch menschlich stets hervorragende Betreuung und Unterstützung. Gleichermaßen möchte ich Frau Dr.-Ing. Daniela Franz für Ihre außerordentliche Leistung bei der Entwicklung des CI-Wizard danken, die die Grundlage für diese Arbeit bildet und überhaupt erst ermöglicht hat.

Herrn Prof. Dr. med. Andreas Dietz, der Klinikdirektor und Ordinarius für HNO der Universitätsklinik Leipzig, danke ich für die Möglichkeit diese Leistung in seiner Abteilung erbringen zu dürfen.

Bei dieser Arbeit wurde die methodische Beratung des Instituts für Klinische Epidemiologie und angewandte Biometrie der Universität Tübingen in Anspruch genommen. Für die Unterstützung möchte ich mich bei Herrn Blumenstock herzlich bedanken.

Nicht zuletzt möchte ich meinen Eltern, Angelika und Jens Tittmann und meiner Schwester und geschätzten Kollegin Dr. med. Dipl.-psych. Mandy Pirlich herzlich danken, die mir das Studium der Humanmedizin ermöglicht haben und mich stets auf diesem Weg unbeschreiblich unterstützt haben. 
